\title{
Prophylactic impact of nano-selenium on performance, carcasses quality, and tissues' selenium concentration using reversed-phase high-performance liquid chromatography during microbial challenge in broiler chickens
}

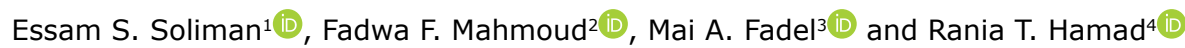

1. Department of Animal Hygiene, Zoonosis and Animal Behavior, Faculty of Veterinary Medicine, Suez Canal University, Ismailia 41522, Egypt; 2. Food Hygiene and Microbiology, Reference Laboratory for Veterinary Quality Control on Poultry Production, Animal Health Research Institute, Agriculture Research Center, Ismailia 41511, Egypt; 3. Pharmacology and Pyrogen Unit, Chemistry and Food Deficiency Department, Animal Health Research Institute, Agriculture Research Center, Dokki, Giza 12618, Egypt; 4. Department of Pathology, Faculty of Veterinary Medicine, Menoufia University, Al Minufya 33511, Egypt.

Corresponding author: Essam S. Soliman, e-mail: soliman.essam@vet.suez.edu.eg

Co-authors: FFM: fadwa012_psg@vet.suez.edu.eg, MAF: dr.mai87@yahoo.com, RTH: drrania_vet2007@yahoo.com Received: 01-03-2020, Accepted: 20-07-2020, Published online: 04-09-2020

doi: www.doi.org/10.14202/vetworld.2020.1780-1797 How to cite this article: Soliman ES, Mahmoud FF, Fadel MA, Hamad RT. (2020) Prophylactic impact of nano-selenium on performance, carcasses quality, and tissues' selenium concentration using reversed-phase high-performance liquid chromatography during microbial challenge in broiler chickens, Veterinary World, 13(9): 1780-1797.

\begin{abstract}
Background and Aim: Nano-selenium (NS) supplementation contributes in improving productivity, performance, and meat quality while reducing public health concern. Influence of NS and inorganic selenium (Se) water additive on performance, carcass quality, immunoglobulin concentration, intestinal microbiota, Se tissue concentrations, and tissue architecture was studied.

Materials and Methods: Two-hundred and sixty 1-day-old Hubbard chicks were randomly grouped into five groups $(5 \times 52)$ and supplemented with 0.5 and $1.0 \mathrm{~mL}$ of NS and inorganic Se $\left(100 \mathrm{mg} . \mathrm{L}^{-1}\right)$. G1, G2, G3, and G4 were challenged with Escherichia coli O157: H7 $2.6 \times 10^{8}$ on the $14^{\text {th }}$ day. A total of 2250 samples, including 250 sera, 250 intestinal swabs, and 1500 organ and tissue samples as liver, spleen, heart, bursa, intestine, and breast muscles, and 250 eviscerated carcasses were collected.

Results: The results revealed a highly significant increase $(\mathrm{p}<0.01)$ in live body weights, weight gains, performance indices, carcasses, and organs weights, whereas immunoglobulin $\mathrm{G}$ and $\mathrm{M}$ concentrations in broilers treated with 0.5 and $1.0 \mathrm{~mL}$ NS, respectively, synchronized reveal a highly significant decline $(\mathrm{p}<0.01)$ in total bacterial and Enterobacteriaceae counts of intestinal swabs and breast muscles, final $\mathrm{pH}_{24}$, and drip loss in broilers treated with 0.5 and $1.0 \mathrm{~mL}$ NS, respectively. Meanwhile, water holding capacity revealed no significant differences between all groups. Reversed-phase high-performance liquid chromatography examination revealed the earlier disappearance of NS residues than inorganic Se from the broiler's liver and muscles. Histopathological photomicrographs of the liver, spleen, bursa of Fabricius, and intestine, as well as, the immunohistochemistry of intestinal sections revealed superior tissue architecture in broilers treated with NS contrary to inorganic Se.
\end{abstract}

Conclusion: The study showed significant stimulation actions of NS on performance, immunity, carcass and meat quality, intestinal and muscles' bacterial load as well as short withdrawal period and nearly normal cellular architecture compared to inorganic Se.

Keywords: broilers, carcass, immunity, nano-selenium, performance, reversed-phase high-performance liquid chromatography.

\section{Introduction}

The poultry industry in the past 10-20 years has been witnessing a large number of feed additives that enhance broiler's productivity and survival Moreover, they were recommended among preventive and biosecurity measures in broiler's farms for their

Copyright: Soliman, et al. Open Access. This article is distributed under the terms of the Creative Commons Attribution 4.0 International License (http://creativecommons.org/licenses/ by/4.0/), which permits unrestricted use, distribution, and reproduction in any medium, provided you give appropriate credit to the original author(s) and the source, provide a link to the Creative Commons license, and indicate if changes were made. The Creative Commons Public Domain Dedication waiver (http:// creativecommons.org/publicdomain/zero/1.0/) applies to the data made available in this article, unless otherwise stated. known actions as immune-stimulants. These additives include probiotics [1], synbiotics [2], Nigella sativa Linn [3], organic acids [4], and trace elements like selenium (Se) [5].

Se has been widely used in the poultry industry for their organic forms (selenomethionine) that can be easily absorbed by red blood cells by means of active transport [6]. Se after absorption and when not metabolized helps in protein synthesis in the liver, kidney, muscles, and gastrointestinal tract [7]. Since Se supplementation is able to improve the broiler's productivity and performance, the main concern has also been in the improvement of meat quality and reduces public health concern [8]. Se is also an essential micronutrient 
because of its unique antioxidant properties [9]. Nano-Se (NS), on the other hand, has been considered a potential supplement for broilers to acquire high catalytic efficiency, low toxicity, and antibacterial activity $[10,11]$. NS water supplementation at lower doses and concentration $(0.5 \mathrm{~mL}$ of NS solution at a rate of $100 \mathrm{mg} . \mathrm{L}^{-1}$ per each 1-1 drinking water) proved to superiorly and significantly improve growth traits, behavior, carcass quality, immunoglobulin concentrations, the histopathological architecture of some organs and tissues (liver, heart, bursa of Fabricius, and spleen), and intestinal microbial load in Arbor and Ross broiler breeds in the presence of heat stress conditions compared to inorganic Se [12]. Se bioavailability is dependent on many factors such as intestinal absorption and biological activation [13], this Se is mostly deposited in muscles, liver, and plasma [14] compared to NS that proved to be less toxicity and high bioavailability in broilers.

High-performance liquid chromatography (HPLC), known as high-pressure liquid chromatography, is a popular analytical technique used for separation, identification, and quantification. HPLC is an advanced technique of column liquid chromatography. The solvent usually flows through a column by gravity but in the HPLC technique, the solvent is forced under high pressures up to 400 psi so that the sample can be separated into different constituents by the difference of relative affinities [15]. HPLC is used increasingly in the analysis of food samples to separate and detect additives, antioxidants, and contaminants. This method breaks down complex mixtures into individual compounds, which, in turn, are identified and quantified by suitable detectors and data handling systems [16]. The previous works established and optimized analytical methods to identify and quantify seleno-amino acids and inorganic Se in biological samples by reversed-phase (RP) chromatography [17].

The study aimed at evaluating the influence of two different doses $(0.5$ and $1.0 \mathrm{~mL})$ of NS (Green synthesized NS) and commercial inorganic Se (sodium selenite, EMIC Veterinary) at a rate of $100 \mathrm{mg} . \mathrm{L}^{-1}$ as a water additive on productive performance, carcass quality (carcass weights and immune organs' weights), meat quality ( $\mathrm{pH}$, drip loss, and water holding capacity), immunoglobulin concentrations, intestinal and muscular microbial counts (total bacterial and Enterobacteriaceae counts), tissue and organs architecture (liver, bursa of Fabricius, spleen, and intestine), and tissue Se (NS and Se) concentrations in liver and muscles of Hubbard broilers challenged with Escherichia coli O157: $\mathrm{H} 72.6 \times 10^{8}$ at the $14^{\text {th }}$ day of age.

\section{Materials and Methods}

\section{Ethical approval}

The guidelines used for the care and use of birds were approved by the Scientific Research
Ethics Committee, Faculty of Veterinary Medicine, Suez Canal University, Egypt, with approval number (2020005).

\section{Study period and location}

The experimental study was conducted from $17-09-2018$ to $25-10-2018$. The study was carried out in the poultry houses experimental units located in the Faculty of Veterinary Medicine, Suez Canal University, Ismailia, Egypt. Performance, carcass quality, immunological, and bacteriological examinations were conducted in Animal, Poultry, and Environmental Hygiene laboratories, Ismailia. Meat characteristics were conducted in Food Hygiene And Microbiology Laboratories, Reference Laboratory for Veterinary Quality Control on Poultry Production, Ismailia. RP-HPLC and electron microscopy were conducted in Pharmacology and Pyrogen Unit Laboratories, Chemistry and Food Deficiency Department, Giza. Histopathology and immunohistochemistry were conducted in Pathology Department laboratories, Al Minufya.

\section{Experimental birds grouping and design}

The experiment was designed for a multifactorial randomized control trial. A total of 260 1-dayold Hubbard chicks were purchased from Alexandria Poultry Company and housed on a deep litter system (wheat hay). The litter was treated before the birds' arrival using sodium metabisulfite $\left(0.05 \mathrm{~g} / \mathrm{m}^{2}\right)$ as recommended by Soliman et al. [18] to control and optimize litter abiotic conditions that when mishandled might lead to the growth and multiplication of pathogenic microorganisms, in addition to minimizing moisture and ammonia in the house microclimate. Chicks were randomly grouped into five groups; each group consisted of 52 chicks (four replicates of 13 birds).

\section{Broiler's management and feeding}

Birds were brooded on their arrival to a rearing site of $34^{\circ} \mathrm{C}$ temperature. The temperature was gradually decreased by $3 \cdot 0-3.5^{\circ} \mathrm{C}$ weekly until achieving a thermo-neutral zone ranged from 21 to $26^{\circ} \mathrm{C}$ by the end of the $3^{\text {rd }}$ week. Ventilation was served by both natural (V-shaped windows) and artificial means (supplying fans) to enhance the broiler's microclimatic conditions and to maintain the natural convection act (Stack effect). A continuous lighting regimen of $23 \mathrm{~h}$ lighting and 1-h darkness was provided using an 18 watt-1750 lumen LED white lamps as recommended by Soliman and Hassan [19]. Birds were supplemented with a standard corn-soybean basal diet to satisfy their nutritional requirement, according to the National Research Council [20] and Applegate and Angel [21] modifications. The ration was based on $23 \%$ crude protein, $4.8 \%$ fat, $3.85 \%$ crude fiber, and $3050 \mathrm{kcal} / \mathrm{kg}$ energy in the starter rations that were provided from day 1 until the $15^{\text {th }}$ day, while grower ration was provided from the $16^{\text {th }}$ day ongoing for the remaining time based on $21 \%$ protein, $5.3 \%$ fat, $3.1 \%$ crude fiber, and $3100 \mathrm{kcal} / \mathrm{kg}$ energy. The ration provided was supplied 
with vitamin and mineral mix that did not include any of the Se forms as requested to prevent the interaction with the water treatment used in the experiment. The vitamin and mineral mix included Vitamin A 4,000,000 IU, Vitamin D3 1,000,000 IU, Vitamin E $50 \mathrm{IU}$, Vitamin K 32,000 mg, Vitamin B1 $1500 \mathrm{mg}$, Vitamin B2 $7000 \mathrm{mg}$, Vitamin B6 $2500 \mathrm{mg}$, Vitamin B12 $13 \mathrm{mg}$, Biotin $110 \mathrm{mg}$, niacin 30,000 mg, calcium pantothenate $10,000 \mathrm{mg}$, folic acid $2500 \mathrm{mg}$, manganese $100,000 \mathrm{mg}$, iodine $1000 \mathrm{mg}$, iron $35,000 \mathrm{mg}$, and copper $12,000 \mathrm{mg}$. The birds were given ad libitum access to water. Mortalities, temperature, and relative humidity were recorded daily during the experiment that was designed to last for 39 days.

Birds were subjected to mass active artificial immunization act using drinking de-chlorinated water against infectious bronchitis using live attenuated virus vaccine (PESTIKAL B1 SPF 1000 dose, H120 $\geq 10^{3.5} \mathrm{EID}_{50} /$ dose) at $7^{\text {th }}$ day, infectious bursal disease using live attenuated virus vaccine (SER-VAC D78 Strain 1000 dose, VMG91 $\geq 10^{3.0} \mathrm{TCID}_{50}$ ) at $13^{\text {th }}$ and $20^{\text {th }}$ days, and Newcastle disease using live lentogenic virus vaccine (PESTIKAL 1000 dose, Lasota $\geq 10^{6.0}$ $\left.\mathrm{EID}_{50}\right)$ at $18^{\text {th }}$ and $28^{\text {th }}$ days.

\section{NS and Se supplement}

NS were prepared as recommended by Gorer and Hodes [22] and Ali et al. [23] using Se powder (Merck 209651, 100 mesh, $\geq 99.5 \%$ trace metals basis) and sodium sulfate (Merck 7757-82-6, Molecular Weight: 142.04 ), as well as, glucose $6 \%$ powder (Merck G7021, powder, BioReagent, $\geq 99.5 \%$ ) as stabilizing and reducing agent, and polyvinyl alcohol (PVA 10,981 , mounting medium with $\mathrm{DABCO}^{\circledR}, 100 \mathrm{~mL}$ ) to prevent deviations in the morphological characters of NS and to protect the molecules from aggregation. The aqueous sodium seleno-sulfate solution was prepared by adding Se powder to sodium sulfate solution, and then optimized by refluxing and heating at $70^{\circ} \mathrm{C}$; the filtrate of the formed solution was treated with glucose and PVA $1 \%$ with refluxing for an extra $6 \mathrm{~h}$. The final product was examined and identified for its size, concentration (100 mg. $\left.\mathrm{L}^{-1}\right)$ and structure using HR-Transmission Electron Microscopy (TEM) JOEL JEM-2010 operated at an accelerating voltage of $200 \mathrm{kV}$ equipped with Gatan digital camera Erlangshen ES500 by dropping the sample on a copper grid coated with a carbon film and ultraviolet (UV)-visible Shimadzu RF5301PC double beam spectrophotometer. TEM characterization revealed a spherical shape for the nanoparticles with $25 \mathrm{~nm}$ in size, and the absorption spectra of the final product were scanned at $200-800 \mathrm{~cm}^{-1}$ using $1 \mathrm{~cm}$ quartz cells. The spectra of the formed product revealed a transition point at $367 \mathrm{~nm}$ with no clear maximum. Meanwhile, commercial inorganic Se was purchased as selenite oily preparation $\left(\mathrm{Na}_{2} \mathrm{SeO}_{3}\right.$, molecular weight 172.94, $100 \mathrm{mg} . \mathrm{L}^{-1}$ ) from the market (EMIC Veterinary).
Synthesized NS and commercial Se (sodium selenite - EMIC Veterinary) at a rate of $100 \mathrm{mg} . \mathrm{L}^{-1}$ were provided to broilers in the drinking water. Treatments were assigned to broiler groups as follow: G1 was supplemented with $0.5 \mathrm{~mL}$ NS $100 \mathrm{mg} . \mathrm{L}^{-1} / \mathrm{L}$ producing a final concentration of $0.05 \mathrm{mg} . \mathrm{L}^{-1}, \mathrm{G} 2$ was supplemented with $1.0 \mathrm{~mL}$ NS $100 \mathrm{mg} . \mathrm{L}^{-1} / \mathrm{L}$ producing a final concentration of $0.1 \mathrm{mg} . \mathrm{L}^{-1}, \mathrm{G} 3$ was supplemented with $0.5 \mathrm{~mL}$ inorganic Se $100 \mathrm{mg} . \mathrm{L}^{-1} / \mathrm{L}$ producing a final concentration of $0.05 \mathrm{mg} . \mathrm{L}^{-1}$, G4 was supplemented with $1.0 \mathrm{~mL}$ inorganic Se $100 \mathrm{mg} . \mathrm{L}^{-1} / \mathrm{L}$ producing a final concentration of $\mathrm{mg} \cdot \mathrm{L}^{-1}$, and $\mathrm{G} 5$ was kept under untreated control.

\section{E. coli 0157: H7 culture propagation and infection}

E. coli $\mathrm{O} 157$ : $\mathrm{H} 76.4 \times 10^{4}$ colony-forming unit culture was purchased from Animal Health Research Institute - Ismailia. The culture was propagated using MacConkey broth and incubated at $44^{\circ} \mathrm{C} / 24 \mathrm{~h}$. Drop plate technique was followed, as $10 \mu \mathrm{L}$ were transferred aseptically from yellow-colored positive MacConkey tubes, dropped onto Eosin Methylene Blue (EMB) agar, and incubated at $37^{\circ} \mathrm{C} / 24 \mathrm{~h}$ [24]. Typical metallic green colonies were counted and picked up. Four out of the five groups (G1, G2, G3, and G4) were challenged with E. coli O157: H7 $2.6 \times 10^{8}$ at the $14^{\text {th }}$ day of age in drinking water [25].

\section{Performance indices (PI)}

Average live body weights (LBW) were determined weekly by weighing 45 birds from each group. The number of weighted birds was calculated using a simple random sampling design [26] with an expected error of $5 \%$ using the following formula:

\section{$\mathrm{n}=1.96^{2} \mathrm{P}_{\exp }\left(1-\mathrm{P}_{\text {exp }}\right) / \mathrm{d} 2$}

where $\mathrm{n}=$ = required sample size, $\mathrm{P}_{\exp }=$ expected prevalence, and $\mathrm{d}=$ desired absolute precision. Weekly feed intakes $(\mathrm{FI} / \mathrm{g})$ in each group were calculated by dividing the total amount consumed by the number of birds in such a group. Body-weight gains (WG/g), feed conversion ratios (FCR/\%), and PI were calculated as recommended by Soliman and Hassan [27].

\section{Sampling}

A total number of 250 birds were sacrificed, including 50 birds per each treatment and control. A total of 2250 samples, including 250 sera, 250 intestinal swabs, 1500 organs, and tissue samples including liver, spleen, heart, bursa, intestine, and breast muscles, and 250 (two sets of 125 samples) eviscerated carcass samples associated with its liver were collected. The blood samples (a total of 250 blood sample for sera separation from 50 birds per each treatment and control) were collected while sacrificing the birds, kept in a water bath at $37^{\circ} \mathrm{C}$ for $20 \mathrm{~min}$, centrifuged at $3500 \mathrm{rpm}$ for $20 \mathrm{~min}$, and non-hemolyzed sera were piped into Eppendorf tubes and stored at $-20^{\circ} \mathrm{C}$ until used for the immunological assay. Carcasses were weighed after de-feathering and evisceration. The liver, heart, spleen, and bursa of Fabricius were 
obtained from each carcass, weighed, and expressed as gram per kilogram carcass weight $(\mathrm{g} / \mathrm{kg})$. Weighed organs such as liver, spleen, and bursa, and intestines were directed for histopathological and immunohistochemistry examination. One set of 125 eviscerated carcass samples was kept frozen until directed for meat quality examinations, and the second set (125 eviscerated carcasses associated with its liver) was kept frozen for $24 \mathrm{~h}$ until directed for RP-HPLC examination for detecting NS and Se tissue residues in correlation to post-sacrificing time factor $\left(1^{\text {st }}, 5^{\text {th }}\right.$, $10^{\text {th }}, 15^{\text {th }}, 20^{\text {th }}, 25^{\text {th }}, 30^{\text {th }}, 35^{\text {th }}$, and $40^{\text {th }}$ days). Intestinal swabs and breast muscle samples were collected on $9 \mathrm{~mL}$ buffered peptone water and directed for bacteriological assessment.

\section{Meat quality assay}

Eviscerated carcass samples were examined for drip loss [28] and water holding capacity [29]. The drip loss was assessed at 0 times and after $72 \mathrm{~h}$ for breast meat packaged in a polyethylene bag, they were weighed at 0 times $\left(\mathrm{W}_{0} / \mathrm{g}\right)$ then stored at $4^{\circ} \mathrm{C}$ for $72 \mathrm{~h}$. The excess moisture was wiped off, breast samples were re-weighed after $72 \mathrm{~h}\left(\mathrm{~W}_{24} / \mathrm{g}\right)$, and the drip loss was calculated with the following formula:

Drip loss $\%=100 \times\left(\mathrm{W}_{0} / \mathrm{g}-\mathrm{W}_{24} / \mathrm{g}\right) / \mathrm{W}_{0} / \mathrm{g}$

Four replicates of $10 \mathrm{~g}$ muscles were sampled, minced, added with $15 \mathrm{~mL}$ of $0.6 \mathrm{M}$ sodium chloride solution into $50 \mathrm{~mL}$ falcon tubes, and mixed using vortex for $1 \mathrm{~min}$. The tubes were refrigerated at $4^{\circ} \mathrm{C}$ for $15 \mathrm{~min}$ and centrifuged at $4^{\circ} \mathrm{C}$ by $3000 \mathrm{rpm}$ for $15 \mathrm{~min}$. The water uptake (\%) was determined by the formula:

Water holding capacity $\%=100 \times\left(\mathrm{W}_{\text {pellet }}-\mathrm{W}_{\text {raw }}\right) / \mathrm{W}_{\text {raw }}$ where $\mathrm{W}_{\text {pellet }}$ was the weight of solid material at the bottom of tubes after centrifugation and $\mathrm{W}_{\text {raw }}$ was the weight of the chicken meat sample used for analysis.

\section{HPLC assay}

Frozen chicken tissue samples $\left(-20^{\circ} \mathrm{C}\right)$ were prepared by partial thawing at room temperature $\left(25^{\circ} \mathrm{C}\right)$ for $30 \mathrm{~min}$, minced, and homogenized in the mincer for $1 \mathrm{~min}$. The samples were subjected to extraction process for NS and Se residues according to Fadel et al. [30] using injection volume, $50 \mu \mathrm{L}$; flow rate, $1.0 \mathrm{~mL} / \mathrm{min}$; UV detection at wavelength, $280 \mathrm{~nm}$ for Se and 332nm for NS; column temperature, ambient; stop time, $10 \mathrm{~min}$; post time, $1 \mathrm{~min}$; and mobile phase $100 \%$ methanol for Se, Methanol: $10 \mathrm{mM}$ citric acid monohydrate $(85 / 15, \mathrm{v} / \mathrm{v}-2.5 \mathrm{pH})$ for NS.

The quantification of residues was obtained and calculated from the area under curves extrapolated automatically by the software (Chem Station, France). The presence of NS in tissues was confirmed by a high-resolution transmission electron microscope at the $20^{\text {th }}$ day (Field Emission Scanning Electron Microscope Model Leo Supra 55, Magnification: $20 \times-900,000 \times$ ), according to Mühlfeld et al. [31].

\section{Immunological profile}

Sera samples were examined for immunoglobulin $\mathrm{G}(\mathrm{IgG})$ and immunoglobulin $\mathrm{M}(\mathrm{IgM})$ concentrations using ROCHE Elecsys 1010 Immunoassay Analyzer [32].

\section{Bacteriological assay}

Intestinal swabs and breast muscle extract samples (a total of 500 samples, including 250 intestinal swabs and 250 breast muscles previously collected while sacrificing 50 birds per each treatment and control) were prepared, according to the American Public Health Association [33]. The samples were subjected to ten-fold serial dilution up to $10^{-7}$. Total bacterial count (TBC) and total Enterobacteriaceae count (TEC) were conducted using a drop plate technique, as recommended by Kim and Lee [34] and Soliman et al. [35]. TBC was performed using standard plate count agar (SPC, SPC Agar, HIMEDIA ${ }^{\circledR} \mathrm{M} 091,500 \mathrm{~g}$ ) at $37^{\circ} \mathrm{C}$ for 24-48 $\mathrm{h}$ and TEC was conducted using EMB Agar (EMB, Levine Eosin Methylene Blue Agar, MU022, $500 \mathrm{~g}$ ) at $37^{\circ} \mathrm{Cfor} 24-48 \mathrm{~h}$. Plates were counted using the Dark-field colony counter (Reichert ${ }^{\mathrm{TM}}$ Dark-filed Quebec ${ }^{\mathrm{TM}}$ Colony Counters - Fisher Scientific), as recommended by Murray et al. [36].

\section{Histopathological examination}

Specimens of the liver, duodenum, bursa of Fabricius, and spleen were removed from broiler chickens (a total of 1000 samples include 250 liver, 250 duodenum, 250 bursa, and 250 spleen samples were collected while sacrificing 50 birds per each treatment and control), washed with $5 \%$ phosphate-buffered saline, and harvested in buffered formalin saline $10 \%$ for histopathological examination, specimens were cut into 5-mm thickness sections, put into tissue cassettes, transferred through a series of alcohols with increasing concentrations for dehydration, cleared by transfer into two changes of xylol, embedded in paraffin, cut into $5 \mu \mathrm{m}$ thickness section, and stained with hematoxylin and eosin (H\&E) [37,38]. Histological sections were examined using a Zeiss Axioplan microscope (Carl Zeiss MicroImaging, Thornwood, NY).

\section{Immunohistochemistry assay}

Immunohistochemistry assay was conducted for the detection of nuclear factor kappa B (NF-KB)/ p65, in duodenal tissues using a standard immunohistochemical method as recommended by Eissa and Shoman [39] using rabbit anti-mouse phospho-NF-кB p65 antibody (Thermo Fisher Scientific, USA) (1: 50-100) which is used to stain cells with activated $\mathrm{NF}-\mathrm{KB}$ transcription factor. The biotin-streptavidin systems were used to observe the markers [40]. Diaminobenzidine allows permanent preparation, so, it is used as a chromogen. Hematoxylin was used as a counterstain. Slides were examined using a Zeiss Axioplan microscope (Carl Zeiss MicroImaging, Thornwood, NY). The captured mages were analyzed using Image J $1.51 \mathrm{p}$ software $(10 \times)$, (Wayne Rasband, NIH) for NF- $\kappa B$ positive cells. 


\section{Statistical analysis}

Statistical analysis was carried out using Statistical Package for the Social Sciences (SPSS version 21.0, IBM Corp., NY, USA) [41]. The data obtained were analyzed statistically using multifactorial analysis of variance (two-tailed ANOVA) to investigate the overall mean prophylactic influence of Se and NS along with the broiler's age and their interactions. The statistical model was summarized as follow:

$Y_{\mathrm{ijk}}=\mu+\alpha_{\mathrm{i}}+\beta_{\mathrm{j}}+(\alpha \beta)_{\mathrm{ij}}+\varepsilon_{\mathrm{ijk}}$

where $Y_{\mathrm{ijk}}$ was the measurement of dependent variables; $\mu$ was overall mean; $\alpha_{j}$ was the fixed effect of the treatments (Se and NS), $\beta_{\mathrm{j}}^{\mathrm{j}}$ was the fixed effect of the birds' age, $(\alpha \beta)_{\mathrm{ij}}$ was the interaction between treatment and broiler age, and $\varepsilon_{\mathrm{ijk}}$ was the random error. Pearson's correlation (r) was calculated to determine the correlation coefficient between immunoglobulin concentrations along with total bacterial and Enterobacteriaceae counts in intestine and breast muscles. Total bacterial and Enterobacteriaceae counts were transformed into logarithm $\left(\log _{10}\right)$ using Microsoft Excel 2016. The significance was expressed as highly significant at $p<0.01$, significant at $p \leq 0.05$, and non-significant at $\mathrm{p}>0.05$.

\section{Results}

\section{Performance traits and crude mortality}

Broilers were observed during the entire experimental fattening cycle for the mortalities. The calculated crude mortality rate revealed a total of eight birds $(3.07 \%)$ concerning the total understudy population size. WG overall means in Table-1 revealed highly significant increases $(\mathrm{p}<0.01)$ in broilers supplemented with $0.5 \mathrm{~mL}$ NS compared to all other groups with no significant differences between broilers supplemented with $0.5 \mathrm{~mL}$ inorganic Se, $1.0 \mathrm{~mL}$ NS, and control group.

Feed intakes overall mean (Table-1) revealed highly significant increases $(\mathrm{p}<0.01)$ in broilers supplemented with $0.5 \mathrm{~mL}$ and $1.0 \mathrm{~mL}$ inorganic Se with

Table-1: Performance indices (Mean \pm SE) of Hubbard broiler supplemented with different concentrations of selenium and nano-selenium.

\begin{tabular}{|c|c|c|c|c|c|}
\hline Groups & Age/week & WG/g & $\mathbf{F I} / \mathbf{g}$ & FCR (\%) & PI \\
\hline \multicolumn{6}{|c|}{ Overall means in broiler groups } \\
\hline G1 & & $325.2^{\mathrm{a}} \pm 5.92$ & $616.7^{c} \pm 0.00$ & $1.8^{\mathrm{e}} \pm 0.03$ & $4.4^{\mathrm{a}} \pm 0.07$ \\
\hline $\mathrm{G} 2$ & & $300.0^{\mathrm{b}} \pm 5.21$ & $622.4^{b} \pm 0.00$ & $1.9^{\mathrm{d}} \pm 0.02$ & $3.7^{b} \pm 0.05$ \\
\hline G3 & & $295.9^{b} \pm 3.36$ & $654.0^{\mathrm{a}} \pm 0.00$ & $2.1^{b} \pm 0.02$ & $3.3^{c} \pm 0.08$ \\
\hline G4 & & $279.7^{c} \pm 2.28$ & $659.4^{\mathrm{a}} \pm 0.00$ & $2.3^{a} \pm 0.01$ & $2.9^{d} \pm 0.04$ \\
\hline G5 & & $297.2^{b} \pm 4.73$ & $626.7^{b} \pm 0.00$ & $2.0^{c} \pm 0.03$ & $3.5^{\mathrm{bc}} \pm 0.08$ \\
\hline $\mathrm{p}$ value & & 0.000 & 0.000 & 0.000 & 0.000 \\
\hline \multicolumn{6}{|c|}{ Interactions between groups by age of birds } \\
\hline \multirow[t]{5}{*}{$\overline{\mathrm{G} 1}$} & $1^{\text {st }}$ & $76.6^{d} \pm 3.05$ & $105.5^{e} \pm 0.01$ & $1.3^{c} \pm 0.05$ & $0.8^{e} \pm 0.05$ \\
\hline & $2^{\text {nd }}$ & $258.2^{c} \pm 3.71$ & $336.1^{d} \pm 0.00$ & $1.3^{c} \pm 0.01$ & $2.9^{d} \pm 0.06$ \\
\hline & $3^{\text {rd }}$ & $516.8^{a} \pm 5.62$ & $892.1^{\mathrm{a}} \pm 0.00$ & $1.7^{b} \pm 0.01$ & $5.1^{c} \pm 0.07$ \\
\hline & $4^{\text {th }}$ & $378.5^{b} \pm 10.70$ & $861.1^{\mathrm{c}} \pm 0.00$ & $2.2^{\mathrm{a}} \pm 0.07$ & $5.6^{b} \pm 0.19$ \\
\hline & $5^{\text {th }}$ & $396.0^{b} \pm 15.96$ & $888.6^{b} \pm 0.01$ & $2.2^{a} \pm 0.09$ & $7.4^{\mathrm{a}} \pm 0.35$ \\
\hline \multirow[t]{5}{*}{ G2 } & $1^{\text {st }}$ & $56.0^{e} \pm 2.08$ & $109.2^{\mathrm{e}} \pm 0.00$ & $1.9^{b} \pm 0.07$ & $0.5^{d} \pm 0.03$ \\
\hline & $2^{\text {nd }}$ & $195.1^{\mathrm{d}} \pm 3.25$ & $345.2^{d} \pm 0.01$ & $1.7^{b} \pm 0.02$ & $1.6^{c} \pm 0.04$ \\
\hline & $3^{\text {rd }}$ & $492.0^{a} \pm 20.64$ & $902.1^{b} \pm 0.01$ & $1.8^{\mathrm{b}} \pm 0.08$ & $4.3^{b} \pm 0.28$ \\
\hline & $4^{\text {th }}$ & $347.9^{`} \pm 23.98$ & $895.4^{c} \pm 0.00$ & $2.6^{a} \pm 0.16$ & $4.4^{b} \pm 0.34$ \\
\hline & $5^{\text {th }}$ & $388.6^{b} \pm 22.99$ & $1018.2^{\mathrm{a}} \pm 0.00$ & $2.7^{a} \pm 0.16$ & $5.8^{\mathrm{a}} \pm 0.41$ \\
\hline \multirow[t]{5}{*}{ G3 } & $1^{\text {st }}$ & $76.9^{d} \pm 1.12$ & $106.1^{d} \pm 0.00$ & $1.3^{c} \pm 0.02$ & $0.8^{d} \pm 0.02$ \\
\hline & $2^{\text {nd }}$ & $228.7 c \pm 7.97$ & $325.1^{c} \pm 0.01$ & $1.4^{c} \pm 0.05$ & $2.4^{c} \pm 0.13$ \\
\hline & $3^{\text {rd }}$ & $507.0^{a} \pm 11.59$ & $902.1^{\mathrm{a}} \pm 0.01$ & $1.7^{b} \pm 0.04$ & $4.8^{\mathrm{b}} \pm 0.14$ \\
\hline & $4^{\text {th }}$ & $337.5^{\mathrm{b}} \pm 7.43$ & $888.8^{b} \pm 0.01$ & $2.6^{a} \pm 0.06$ & $4.5^{b} \pm 0.10$ \\
\hline & $5^{\text {th }}$ & $350.2^{b} \pm 9.67$ & $890.1^{b} \pm 0.00$ & $2.5^{\mathrm{a}} \pm 0.07$ & $6.0^{\mathrm{a}} \pm 0.20$ \\
\hline \multirow[t]{5}{*}{ G4 } & $1^{\text {st }}$ & $50.6^{\mathrm{e}} \pm 0.54$ & $112.3^{d} \pm 0.00$ & $2.2^{\mathrm{b}} \pm 0.02$ & $0.4^{d} \pm 0.01$ \\
\hline & $2^{\text {nd }}$ & $166.0^{\mathrm{d}} \pm 2.84$ & $354.1^{\mathrm{c}} \pm 0.01$ & $2.1^{b} \pm 0.03$ & $1.2^{c} \pm 0.03$ \\
\hline & $3^{\text {rd }}$ & $461.8^{a} \pm 6.20$ & $906.1^{\mathrm{b}} \pm 0.02$ & $1.9^{c} \pm 0.02$ & $3.6^{b} \pm 0.07$ \\
\hline & $4^{\text {th }}$ & $385.4^{b} \pm 8.23$ & $902.4^{b} \pm 0.01$ & $2.3^{b} \pm 0.05$ & $4.7^{a} \pm 0.11$ \\
\hline & $5^{\text {th }}$ & $334.8^{c} \pm 9.90$ & $1022.1^{\mathrm{a}} \pm 0.01$ & $3.0^{\mathrm{a}} \pm 0.08$ & $4.7^{a} \pm 0.17$ \\
\hline \multirow[t]{5}{*}{ G5 } & $1^{\text {st }}$ & $58.0^{d} \pm 5.47$ & $109.1^{\mathrm{d}} \pm 0.01$ & $1.8^{\mathrm{b}} \pm 0.05$ & $0.5^{d} \pm 0.02$ \\
\hline & $2^{\text {nd }}$ & $211.1^{\mathrm{c}} \pm 9.12$ & $331.1^{\mathrm{c}} \pm 0.00$ & $1.5^{c} \pm 0.05$ & $2.0^{c} \pm 0.14$ \\
\hline & $3^{\text {rd }}$ & $504.6^{a} \pm 8.57$ & $914.2^{\mathrm{a}} \pm 0.00$ & $1.8^{\mathrm{b}} \pm 0.03$ & $4.5^{b} \pm 0.09$ \\
\hline & $4^{\text {th }}$ & $360.4^{b} \pm 4.42$ & $887.1^{\mathrm{b}} \pm 0.00$ & $2.4^{a} \pm 0.03$ & $4.7^{b} \pm 0.06$ \\
\hline & $5^{\text {th }}$ & $352.1^{b} \pm 9.62$ & $892.1^{b} \pm 0.00$ & $2.5^{a} \pm 0.07$ & $6.0^{\mathrm{a}} \pm 0.19$ \\
\hline$p$ value & & 0.000 & 0.000 & 0.000 & 0.000 \\
\hline
\end{tabular}

Means carrying different superscripts in the same column are significantly different at $(p \leq 0.05)$ or highly significantly different at $(p<0.01)$. Means carrying the same superscripts in the same column are non-significantly different at $\mathrm{p}>0.05$. G1=Hubbard with $0.5 \mathrm{~mL}$ nano-selenium $/ 1 \mathrm{~L}$ drinking water, $\mathrm{G} 2=$ Hubbard with $1.0 \mathrm{~mL}$ nano-selenium/ $1 \mathrm{~L}$ drinking water, G3=Hubbard with $0.5 \mathrm{~mL}$ selenium/ $1 \mathrm{~L}$ drinking water), G4=Hubbard with $1.0 \mathrm{~mL}$ selenium/1 L drinking water, and $\mathrm{G} 5=$ control. WG $=$ Weight gain, $\mathrm{FI}=$ Feed intake, FCR=Feed conversion ratio, and PI=Performance index, $\mathrm{SE}=$ Standard error 
no significant differences between the two groups compared to broilers supplemented with NS and to control broilers.

FCR, as shown in Table-1, revealed highly significant improvement $(p<0.01)$ in broilers supplemented with $0.5 \mathrm{~mL} \mathrm{NS}, 1.0 \mathrm{~mL} \mathrm{NS}$, control, $0.5 \mathrm{~mL}$ inorganic $\mathrm{Se}$, and $1.0 \mathrm{~mL}$ inorganic Se, respectively. The calculated improvement of FCR in G1 and G2 broilers supplemented with NS $(0.5$ and $1.0 \mathrm{~mL})$ and in the G5 control group might be attributed to the lower feed intake (numerator) and higher WG (denominator) compared to G3 and G4 broilers supplemented with inorganic Se (sodium selenite, EMIC Veterinary).

Overall means of PI in Table-1 revealed highly significant increases $(p<0.01)$ in broilers supplemented with $0.5 \mathrm{~mL} \mathrm{NS}, 1.0 \mathrm{~mL} \mathrm{NS}$, control, $0.5 \mathrm{~mL}$ inorganic Se, and $1.0 \mathrm{~mL}$ inorganic Se, respectively, with no significant differences between broilers supplemented with $1.0 \mathrm{~mL}$ NS and $0.5 \mathrm{~mL}$ Se with the control group. The calculated improvement of performance index in G1 and G2 broilers supplemented with NS ( 0.5 and $1.0 \mathrm{~mL})$ and in the G5 control group might be attributed to the higher body weight per $\mathrm{kg}$ (numerator) and higher FCR (denominator) compared to $\mathrm{G} 3$ and $\mathrm{G} 5$ broilers supplemented with inorganic Se (sodium selenite, EMIC Veterinary).

\section{Live body, carcass, and organs weight}

LBW, as revealed in Table- 2 , recorded highly significant increases $(p<0.01)$ in broilers supplemented with $0.5 \mathrm{~mL} \mathrm{NS}, 1.0 \mathrm{~mL} \mathrm{NS}, 0.5 \mathrm{~mL}$ inorganic Se, $1.0 \mathrm{~mL}$ inorganic Se, and control, respectively, with no significant differences between LBW of broilers supplemented with $1.0 \mathrm{~mL}$ inorganic Se and control untreated broilers. Carcasses' weights revealed highly significant increases $(\mathrm{p}<0.01)$ in broilers supplemented with $0.5 \mathrm{~mL} \mathrm{NS}, 1.0 \mathrm{~mL} \mathrm{NS}, 0.5 \mathrm{~mL}$ inorganic Se, 1.0 $\mathrm{mL}$ inorganic Se, and control with no significant differences between carcass weight values in broilers supplemented with 0.5 inorganic Se and $1.0 \mathrm{~mL} \mathrm{NS}$.

The liver weights revealed in Table- 2 highly significant increases $(p<0.01)$ in broilers supplemented with $0.5 \mathrm{~mL} \mathrm{NS}, 1.0 \mathrm{~mL} \mathrm{NS}, 0.5 \mathrm{~mL}$ inorganic $\mathrm{Se}$, and
$1.0 \mathrm{~mL}$ inorganic Se, respectively, compared to control group with no significant differences between liver weights from broilers supplemented with 0.5 and $1.0 \mathrm{~mL}$ inorganic Se (sodium selenite, EMIC Veterinary). The spleen weights revealed highly significant increases in broilers supplemented with $0.5 \mathrm{~mL} \mathrm{NS}, 1.0 \mathrm{~mL} \mathrm{NS}$, $0.5 \mathrm{~mL} \mathrm{Se}$, and $1.0 \mathrm{~mL} \mathrm{Se}$, respectively, compared to the control group with no significant differences between spleen weights from broilers supplemented with $1.0 \mathrm{~mL}$ NS and $0.5 \mathrm{~mL}$ Se (Table-2). Heart and bursa of Fabricius weights (Table-2) revealed highly significant increases $(\mathrm{p}<0.01)$ in broilers supplemented with $0.5 \mathrm{~mL} \mathrm{NS}, 1.0 \mathrm{~mL} \mathrm{NS}, 0.5 \mathrm{~mL}$ inorganic Se, and $1.0 \mathrm{~mL}$ inorganic Se, respectively, compared to control group.

\section{Meat quality parameters}

Initial $\mathrm{pH}_{0}$ values revealed highly significant declines $(\mathrm{p}<0.01)$, as shown in Table-3, in control and broilers supplemented with $0.5 \mathrm{~mL}$ inorganic Se with no significant differences between the values in broilers supplemented with $0.5 \mathrm{~mL} \mathrm{NS}, 1.0 \mathrm{~mL} \mathrm{NS}$, and $1.0 \mathrm{~mL}$ inorganic $\mathrm{Se}$. Meanwhile, $\mathrm{pH}_{24}$ values revealed highly significant declines $(p<0.01)$ in broilers supplemented with $0.5 \mathrm{~mL}$ NS compared to control and other supplemented groups.

Drip loss (Table-3) revealed highly significant declines in broilers supplemented with 0.5 and $1.0 \mathrm{~mL}$ NS with no significant differences between the two groups. Meanwhile, water holding capacity (Table-3) revealed no significant differences between all supplemented groups and control.

\section{Immunoglobulin concentrations and bacterial loads}

IgG and $\operatorname{IgM}$ concentrations, in Table- 4 , revealed highly significant increases $(\mathrm{p}<0.01)$ in broilers supplemented with $0.5 \mathrm{~mL} \mathrm{NS}, 1.0 \mathrm{~mL} \mathrm{NS}, 1.0 \mathrm{~mL}$ inorganic Se, $0.5 \mathrm{~mL}$ inorganic $\mathrm{Se}$, and control group, respectively, with no significant differences in IgG concentrations between broilers supplemented with 0.5 and $1.0 \mathrm{~mL}$ inorganic Se.

A synchronized highly significant declines $(p<0.01)$, as shown in Table-4, in total bacterial and

Table-2: Carcass quality (Mean \pm SE) and organs percentage (Mean \pm SE) of Hubbard broiler supplemented with different concentrations of selenium and nano-selenium.

\begin{tabular}{lcccccc}
\hline Groups & \multirow{2}{*}{ LBW/g } & \multicolumn{2}{c}{ Carcass weight/g } & \multicolumn{4}{c}{ Immune and edible organs weights/g } \\
\cline { 3 - 7 } & & Liver & Spleen & Heart & Bursa \\
\hline \multicolumn{2}{l}{ Overall means in broiler groups } \\
\hline G1 & $2294^{\mathrm{a}} \pm 21.6$ & $2016^{\mathrm{a}} \pm 15.8$ & $50.4^{\mathrm{a}} \pm 0.20$ & $3.0^{\mathrm{a}} \pm 0.015$ & $12.9^{\mathrm{a}} \pm 0.03$ & $1.6^{\mathrm{a}} \pm 0.00$ \\
G2 & $1994^{\mathrm{b}} \pm 21.6$ & $1761^{\mathrm{b}} \pm 15.8$ & $44.6^{\mathrm{b}} \pm 0.20$ & $2.4^{\mathrm{b}} \pm 0.015$ & $10.4^{\mathrm{b}} \pm 0.03$ & $1.3^{\mathrm{b}} \pm 0.01$ \\
G3 & $1859^{\mathrm{c}} \pm 25.3$ & $1741^{\mathrm{b}} \pm 18.6$ & $40.7^{\mathrm{c}} \pm 0.23$ & $2.3^{\mathrm{b}} \pm 0.018$ & $9.7^{\mathrm{c}} \pm 0.04$ & $1.1^{\mathrm{c}} \pm 0.01$ \\
G4 & $1778^{\mathrm{d}} \pm 21.6$ & $1538^{\mathrm{c}} \pm 15.8$ & $40.4^{\mathrm{c}} \pm 0.20$ & $2.0^{\mathrm{c}} \pm 0.015$ & $9.0^{\mathrm{d}} \pm 0.03$ & $0.9^{\mathrm{d}} \pm 0.01$ \\
G5 & $1731^{\mathrm{d}} \pm 25.3$ & $1359^{\mathrm{d}} \pm 18.6$ & $23.1^{\mathrm{d}} \pm 0.23$ & $1.3^{\mathrm{d}} \pm 0.018$ & $5.6^{\mathrm{e}} \pm 0.04$ & $0.6^{\mathrm{e}} \pm 0.01$ \\
p value & 0.000 & 0.000 & 0.041 & 0.033 & 0.020 & 0.012 \\
\hline
\end{tabular}

Means carrying different superscripts in the same column are significantly different at $(p \leq 0.05)$ or highly significantly different at $(p<0.01)$. Means carrying the same superscripts in the same column are non-significantly different at $(p>0.05)$. G1=Hubbard with $0.5 \mathrm{~mL}$ nano-selenium $/ 1 \mathrm{~L}$ drinking water, $\mathrm{G} 2=$ Hubbard with $1.0 \mathrm{~mL}$ nano-selenium/ $1 \mathrm{~L}$ drinking water, G3=Hubbard with $0.5 \mathrm{~mL}$ selenium/1 L drinking water), G4=Hubbard with $1.0 \mathrm{~mL}$ selenium/1 L drinking water, and $\mathrm{G} 5=$ Control. LBW=Live body weight, $\mathrm{SE}=$ Standard error 
Table-3: Meat quality parameters (Mean \pm SE) in Hubbard broilers supplemented with different concentrations of selenium and nano-selenium.

\begin{tabular}{lcccc}
\hline Groups & $\mathbf{p H}_{\mathbf{0}}$ & $\mathbf{p H}_{\mathbf{2 4}}$ & Drip loss $\%$ & Water holding capacity \% \\
\hline \multicolumn{2}{l}{ Overall means in broiler groups } & & & \\
\hline G1 & $7.21^{\mathrm{a}} \pm 0.059$ & $5.56^{\mathrm{c}} \pm 0.144$ & $1.54^{\mathrm{c}} \pm 0.219$ & $9.60^{\mathrm{a}} \pm 1.281$ \\
G2 & $7.25^{\mathrm{a}} \pm 0.021$ & $6.08^{\mathrm{b}} \pm 0.035$ & $2.68^{\mathrm{b}} \pm 0.397$ & $7.70^{\mathrm{a}} \pm 0.854$ \\
G3 & $6.98^{\mathrm{b}} \pm 0.103$ & $6.47^{\mathrm{a}} \pm 0.185$ & $3.33^{\mathrm{b}} \pm 0.200$ & $8.10^{\mathrm{a}} \pm 0.680$ \\
G4 & $7.21^{\mathrm{a}} \pm 0.012$ & $6.18^{\mathrm{ab}} \pm 0.016$ & $3.92^{\mathrm{a}} \pm 0.131$ & $8.85^{\mathrm{a}} \pm 0.427$ \\
G5 & $6.58^{\mathrm{c}} \pm 0.046$ & $5.73^{\mathrm{c}} \pm 0.063$ & $4.89^{\mathrm{a}} \pm 0.931$ & $5.80^{\mathrm{a}} \pm 0.081$ \\
p value & 0.000 & 0.000 & 0.002 & 0.236 \\
\hline
\end{tabular}

Means carrying different superscripts in the same column are significantly different at $(p \leq 0.05)$ or highly significantly different at $p<0.01$. Means carrying the same superscripts in the same column are non-significantly different at $p>0.05$. G1=Hubbard with $0.5 \mathrm{~mL}$ nano-selenium/1 L drinking water, G2=Hubbard with $1.0 \mathrm{~mL}$ nano-selenium/1 L drinking water, G3=Hubbard with $0.5 \mathrm{~mL}$ selenium/1 L drinking water), G4=Hubbard with $1.0 \mathrm{~mL}$ selenium/1 L drinking water, and $\mathrm{G} 5=$ Control. $\mathrm{pH}_{0}=$ Hydrogen ion concentrations at 0 time, $\mathrm{pH}_{24}=$ Hydrogen ion concentrations $24 \mathrm{~h}$

Table-4: Immunoglobulin concentration and logarithm bacterial load (Mean $\pm \mathrm{SE}$ ) of Hubbard broiler supplemented with different concentrations of selenium and nano-selenium.

\begin{tabular}{|c|c|c|c|c|c|c|}
\hline \multirow[t]{3}{*}{ Groups } & \multicolumn{2}{|c|}{ Immunoglobulin concentration } & \multicolumn{4}{|c|}{ Bacterial counts } \\
\hline & \multirow[t]{2}{*}{$\operatorname{IgG}(\mathrm{mg} / \mathrm{dl})$} & \multirow[t]{2}{*}{$\operatorname{Ig} M(\mathrm{mg} / \mathrm{dl})$} & \multicolumn{2}{|c|}{ Intestinal swabs } & \multicolumn{2}{|c|}{ Breast muscles } \\
\hline & & & $\begin{array}{c}\text { Log. TBC } \\
\text { (CFU/mL) }\end{array}$ & $\begin{array}{c}\text { Log. TEC } \\
\text { (CFU/mL) }\end{array}$ & $\begin{array}{c}\text { Log. TBC } \\
\text { (CFU/mL) }\end{array}$ & $\begin{array}{l}\text { Log. TEC } \\
(\mathrm{CFU} / \mathrm{mL})\end{array}$ \\
\hline \multicolumn{7}{|c|}{ Overall means in broiler groups } \\
\hline G1 & $1710.3^{a} \pm 2.3$ & $390.1^{\mathrm{a}} \pm 1.8$ & $5.39^{d} \pm 0.018$ & $3.99^{e} \pm 0.013$ & $3.64^{\mathrm{d}} \pm 0.015$ & $1.64^{\mathrm{e}} \pm 0.017$ \\
\hline G2 & $1680.0^{\mathrm{b}} \pm 5.7$ & $373.6^{\mathrm{b}} \pm 1.6$ & $5.80^{`} \pm 0.016$ & $4.22^{c} \pm 0.012$ & $4.23^{c} \pm 0.014$ & $2.10^{\complement} \pm 0.016$ \\
\hline G3 & $1619.1^{\complement} \pm 6.9$ & $333.5^{d} \pm 2.1$ & $5.93^{b} \pm 0.021$ & $4.35^{b} \pm 0.015$ & $4.51^{\mathrm{b}} \pm 0.018$ & $2.39^{b} \pm 0.020$ \\
\hline G4 & $1626.6^{\complement} \pm 4.7$ & $354.4^{c} \pm 1.8$ & $6.54^{\mathrm{a}} \pm 0.018$ & $4.48^{\mathrm{a}} \pm 0.013$ & $4.57^{a} \pm 0.015$ & $2.44^{\mathrm{a}} \pm 0.017$ \\
\hline G5 & $1366.0^{d} \pm 8.8$ & $274.2^{\mathrm{e}} \pm 2.1$ & $3.88^{\mathrm{e}} \pm 0.021$ & $4.05^{d} \pm 0.015$ & $2.77 \mathrm{e} \pm 0.018$ & $1.74^{\mathrm{d}} \pm 0.020$ \\
\hline $\mathrm{p}$ value & 0.000 & 0.001 & 0.000 & 0.000 & 0.000 & 0.000 \\
\hline
\end{tabular}

Means carrying different superscripts in the same column are significantly different at $(p \leq 0.05)$ or highly significantly different at $(p<0.01)$. Means carrying the same superscripts in the same column are non-significantly different at $(p>0.05)$. $\mathrm{G} 1=$ Hubbard with $0.5 \mathrm{~mL}$ nano-selenium/ $1 \mathrm{~L}$ drinking water, $\mathrm{G} 2=$ Hubbard with $1.0 \mathrm{~mL}$ nano-selenium/1 $\mathrm{L}$ drinking water, $\mathrm{G} 3=$ Hubbard with $0.5 \mathrm{~mL}$ selenium/ $1 \mathrm{~L}$ drinking water), $\mathrm{G} 4=$ Hubbard with $1.0 \mathrm{~mL}$ selenium/ $1 \mathrm{~L}$ drinking water, and G5=Control. IgG=Immunoglobulin G, IgM=Immunoglobulin M, TBC=Total Bacterial count, TEC=Total Enterobacteriaceae count, $\mathrm{CFU}=$ Colony-forming unit, $\mathrm{SE}=$ Standard error

Enterobacteriaceae counts of intestinal swabs and breast muscles in broilers supplemented with 0.5 and $1.0 \mathrm{~mL}$ NS compared to other supplemented groups, with high significant declines $(\mathrm{p}<0.01)$ in broilers supplemented with $0.5 \mathrm{~mL}$ NS compared to those supplemented with $1.0 \mathrm{~mL}$ NS.

Pearson's correlation in Table-5 indicated highly significant positive strong correlations $(\mathrm{r}=0.714 ; 0.637$, $\mathrm{p}<0.01)$ between IgG with the TBC of intestinal swabs and breast muscles, respectively. Meanwhile, IgM revealed highly significant positive strong and medium correlations $(r=0.619 ; 0.504, p<0.01)$ with the TBC of intestinal swabs and breast muscles, respectively.

\section{Se and NS tissue residues}

The quantification of NS and Se residues in the liver and muscles of broilers in Table- 6 showed highly significant declines $(\mathrm{p} \leq 0.01)$ of NS residues in broilers supplemented with 0.5 and $1.0 \mathrm{~mL} \mathrm{NS}$ compared to Se residues in broilers supplemented with 0.5 and $1.0 \mathrm{~mL}$ inorganic Se. Highly significant increases $(\mathrm{p}<0.001)$ in the concentration of NS and Se residues as revealed in Figures- 1 and 2 were detected in the liver compared to muscles. Electron microscopy images that were taken on the $20^{\text {th }}$ day as shown in Figure-3, revealed
Table-5: Correlation coefficient between bacterial load in the intestine and/or breast muscles with IgG concentration (above diagonal) and IgM concentration (below diagonal) of Hubbard broiler supplemented with different concentration of selenium and nano-selenium.

\begin{tabular}{lccccc}
\hline $\mathbf{r}$ & IgG & TBCI & TBCB & TECI & TECB \\
\hline IgM & 1 & $0.714 * *$ & $0.637 * *$ & 0.134 & 0.148 \\
TBCI & $0.619 * *$ & 1 & $0.960 * *$ & $0.750 * *$ & $0.745 * *$ \\
TBCB & $0.504 * *$ & $0.960 * *$ & 1 & $0.813 * *$ & $0.833 * *$ \\
TECI & -0.005 & $0.750 * *$ & $0.813 * *$ & 1 & $0.950 * *$ \\
TECB & -0.013 & $0.745 * *$ & $0.833 * *$ & $0.950 * *$ & 1 \\
\hline
\end{tabular}

**. Correlation is significant at the 0.01 level.

*. Correlation is significant at the 0.05 level. Ns. Correlation is non-significant at the 0.05 level. IgG=Immunoglobulin IgG, IgM=Immunoglobulin IgM, TBCI=Total Bacterial Count in the intestine, $T B C B=$ Total Bacterial Count in Breast Muscle, TECI=Total Enterobacteriaceae Count in the intestine, $\mathrm{TECB}=$ Total Enterobacteriaceae Count in breast muscle, $r=$ Pearson's correlation coefficient

the presence of NS particles in the liver of broiler supplemented with $1 \mathrm{~mL}$ NS (0.1 mg.L ${ }^{-1}$, Figure-3a) and its disappearance from the liver of broilers supplemented with $0.5 \mathrm{~mL}$ NS (0.05 mg.L $\mathrm{L}^{-1}$, Figure-3b) compared to control (Figure-3c). Inorganic $\mathrm{Se}(0.5$ and $1.0 \mathrm{~mL}$ ) was detectable in both liver and muscles up to 
Table-6: Selenium and nano-selenium tissue residues (Mean $\pm \mathrm{SE}$ ) in the liver and muscle of Hubbard broilers using RP-HPLC.

\begin{tabular}{lcc}
\hline Groups & Age/days & \multicolumn{2}{c}{$\begin{array}{c}\text { Tissue residues } \\
(\text { Mean } \pm \text { SE) } \boldsymbol{\mu g} / \mathbf{g}\end{array}$} \\
\cline { 2 - 3 } & Muscles & Liver \\
\hline G1 & $0.158^{\mathrm{d}} \pm 0.006$ & $0.221^{\mathrm{d}} \pm 0.010$ \\
G2 & $0.427^{\mathrm{b}} \pm 0.003$ & $0.716^{\mathrm{b}} \pm 0.011$ \\
G3 & $0.338^{\mathrm{c}} \pm 0.002$ & $0.448^{\mathrm{c}} \pm 0.008$ \\
G4 & $0.830^{\mathrm{a}} \pm 0.002$ & $1.408^{\mathrm{a}} \pm 0.010$ \\
p value & 0.000 & 0.000 \\
\hline
\end{tabular}

\section{Selenium*age}

G1

G2

$\begin{array}{cc}1^{\text {st }} & 0.8780^{\mathrm{a}} \pm 0.039 \\ 5^{\text {th }} & 0.4504^{\mathrm{b}} \pm 0.016 \\ 10^{\text {th }} & 0.1620^{\mathrm{c}} \pm 0.029 \\ 15^{\text {th }} & 0.0847^{\mathrm{d}} \pm 0.005 \\ 20^{\text {th }} & \text { ND } \\ 25^{\text {th }} & \text { ND } \\ 30^{\text {th }} & \text { ND } \\ 35^{\text {th }} & \text { ND } \\ 40^{\text {th }} & \text { ND } \\ 45^{\text {th }} & \text { ND }\end{array}$

$5^{\text {th }}$

$10^{\text {th }}$

$15^{\text {th }}$

$20^{\text {th }}$

$25^{\text {th }}$

$30^{\text {th }}$

$35^{\text {th }}$

$40^{\text {th }}$

$45^{\text {th }}$

G3

$1.8375^{\mathrm{a}} \pm 0.062$

$0.9208^{\mathrm{b}} \pm 0.034$

$0.4207 \_ \pm 0.012$

$0.1448^{\mathrm{d}} \pm 0.016$

$0.0571^{\mathrm{e}} \pm 0.004$

ND

ND

ND

ND

ND

$1.0683^{\mathrm{a}} \pm 0.026$

$0.9109^{\mathrm{b}} \pm 0.002$

$0.7427^{c} \pm 0.025$

$0.5249^{d} \pm 0.009$

$0.4058^{\mathrm{e}} \pm 0.003$

$0.3238^{f} \pm 0.006$

$0.1797^{9} \pm 0.012$

$0.0918^{\mathrm{h}} \pm 0.003$

$0.0182^{i} \pm 0.004$ ND

$2.0827^{a} \pm 0.039$

$1.5024^{\mathrm{b}} \pm 0.010$

$1.2930^{\circ} \pm 0.021$

$1.0913^{\mathrm{d}} \pm 0.020$

$0.8077^{\mathrm{e}} \pm 0.007$

$0.6332^{\mathrm{f}} \pm 0.005$

$0.4805^{\mathrm{g}} \pm 0.025$

$0.2486^{\mathrm{h}} \pm 0.032$

$0.1197 \pm 0.010$

$0.0367^{\mathrm{j}} \pm 0.005$

0.000

$1.0193^{\mathrm{a}} \pm 0.006$

$0.6057^{\mathrm{b}} \pm 0.034$

$0.3699^{\circ} \pm 0.020$

$0.1591^{\mathrm{d}} \pm 0.022$

$0.0562^{\mathrm{e}} \pm 0.005$

ND

ND

ND

ND

ND

$2.0409^{\mathrm{a}} \pm 0.030$

$1.1663^{\mathrm{b}} \pm 0.075$

$0.6756^{c} \pm 0.024$

$0.3311^{\mathrm{d}} \pm 0.013$

$0.1550^{\mathrm{e}} \pm 0.011$

$0.0790^{f} \pm 0.003$

$0.0323^{9} \pm 0.006$

ND

ND

ND

$1.9262^{\mathrm{a}} \pm 0.052$

$1.5568^{\mathrm{b}} \pm 0.054$

$1.0897 \div 0.020$

$0.9604^{c} \pm 0.022$

$0.6390^{\mathrm{d}} \pm 0.049$

$0.5191^{\mathrm{e}} \pm 0.014$

$0.2281^{f} \pm 0.063$

$0.1059^{9} \pm 0.007$

$0.0873^{\mathrm{h}} \pm 0.003$

$0.0448 \pm 0.001$

$2.9271^{\mathrm{a}} \pm 0.037$

$2.3936^{\mathrm{b}} \pm 0.064$

$2.0509^{c} \pm 0.040$

$1.7981^{\mathrm{d}} \pm 0.017$

$1.1194^{\mathrm{e}} \pm 0.065$

$1.1072^{\mathrm{f}} \pm 0.003$

$0.9718^{g} \pm 0.025$

$0.8426^{\mathrm{h}} \pm 0.034$

$0.2219 \pm 0.011$

0.000 $0.6441^{i} \pm 0.032$

Means carrying different superscripts in the same column are significantly different at $p \leq 0.05$ or highly significantly different at $p<0.01$. Means carrying the same superscripts in the same column are non-significantly different at $\mathrm{p}>0.05$. G1 $=$ Hubbard with $0.5 \mathrm{~mL}$ nano-selenium $/ 1 \mathrm{~L}$ drinking water, G2=Hubbard with $1.0 \mathrm{~mL}$ nano-selenium/1 $L$ drinking water, $\mathrm{G} 3=$ Hubbard with $0.5 \mathrm{~mL}$ selenium/1 $\mathrm{L}$ drinking water, $\mathrm{G} 4=$ Hubbard with $1.0 \mathrm{~mL}$ selenium/1 $\mathrm{L}$ drinking water, and $\mathrm{G} 5=$ Control. ND=Not detected, $\mathrm{SE}=$ Standard error

$45^{\text {th }}$-day samples, $0.5 \mathrm{~mL}$ NS disappeared in muscles at the $20^{\text {th }}$ day and in liver at the $30^{\text {th }}$-day samples, and $1.0 \mathrm{~mL}$ NS disappeared in muscles at $30^{\text {th }}$ day and in liver at $35^{\text {th }}$-day samples. Thus, NS residues disappeared earlier than inorganic Se from broiler tissues (liver and muscles). The results of the examination by a high-resolution transmission electron microscope confirmed the presence of NS in the liver sample of G1 on the $20^{\text {th }}$ day and disappeared on the $30^{\text {th }}$ day.

\section{Tissue architecture}

Liver photomicrographs revealed in Figure-4a congestion of central vein and portal blood vessels, hepatic cells showed degeneration with mild vaculation of cytoplasm and moderate mononuclear cell infiltration in broilers supplemented with $0.5 \mathrm{~mL}$ NS. The liver of broilers supplemented with $1.0 \mathrm{~mL}$ NS (Figure-4b) showed congestion of central vein and hepatic cells showed degeneration with severe vaculation of cytoplasm and mononuclear cell infiltration, with multiple areas of hemorrhage. Broilers supplemented with $0.5 \mathrm{~mL}$ inorganic Se showed in Figure-4c congestion of portal blood vessels, severe biliary cirrhosis, while hepatocytes showed moderate degeneration, cytoplasmic vaculation, and mononuclear cell infiltration. The liver of broilers supplemented with $1.0 \mathrm{~mL}$ inorganic Se showed in Figure-4d severe degeneration of hepatocytes, severe intrahepatic fibrosis, and severe mononuclear cell infiltration compared to normal architecture in Figure-4e.

Intestinal histopathological examination of broilers supplemented with $0.5 \mathrm{~mL}$ NS revealed in Figure-5a maintenance of intestinal villi, glands, and muscular layer with mild destruction of lining epithelium of villi compared to normal view in Figure-5e. Broilers supplemented with $1.0 \mathrm{~mL}$ NS showed in Figure-5b maintained intestinal villi with increased length of villi, other areas showed degeneration of villi with an increased number of goblet cells. Figure-5c revealed severe degeneration of intestinal villi with a maintained glandular and muscular layer in broilers supplemented with $0.5 \mathrm{~mL}$ inorganic Se. The intestine of broilers supplemented with $1.0 \mathrm{~mL}$ inorganic Se revealed (Figure-5d) severe degenerations of intestinal villi remnant was present, with maintained glandular and muscular layer compared to normal view in Figure-4e.

Photomicrographs of the bursa of Fabricius in comparison to normal view in Figure-6e showed mild depletion of lymphoid follicles in broilers supplemented with $0.5 \mathrm{~mL}$ NS (Figure-6a), hyperplasia of follicular epithelium and moderate lymphoid depletion in the lymphoid follicles of broilers supplemented with $1.0 \mathrm{~mL}$ NS (Figure-6b), severe hyperplasia of follicular epithelium and severe depletion of lymphocytes which was replaced by an edematous fluid with increased interfollicular fibrosis in broilers supplemented with $0.5 \mathrm{~mL}$ inorganic Se (Figure-6c), and severe interfollicular fibrosis, severe depletion of lymphoid follicles, and hyperplasia of follicles epithelium in broilers supplemented with $1.0 \mathrm{~mL}$ inorganic Se (Figure-6d). 


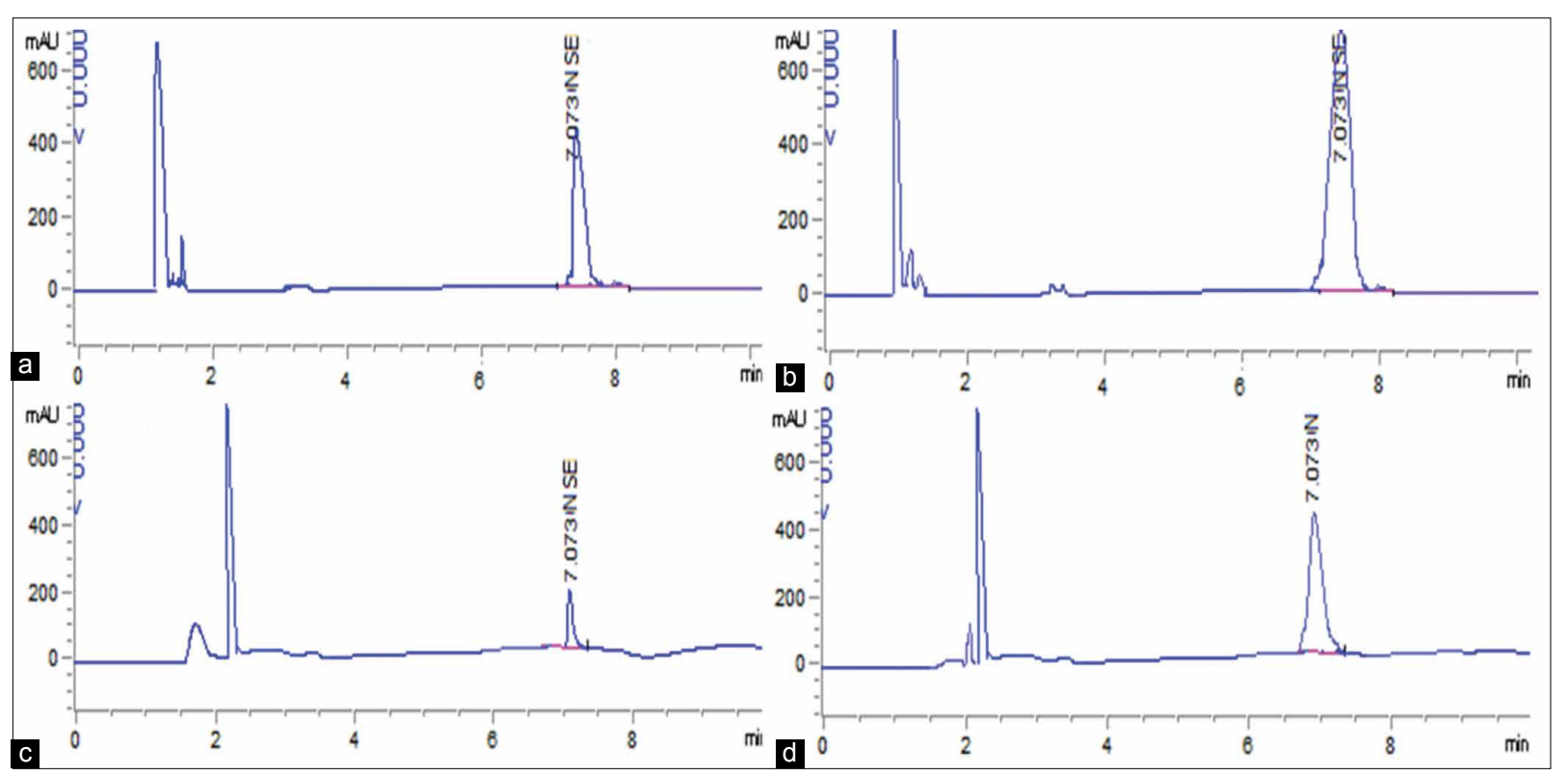

Figure-1: Liquid chromatography of nano-selenium residues in liver and muscles at 1 st day following supplementation with: (a) $0.5 \mathrm{~mL}$ of $100 \mathrm{mg} \cdot \mathrm{L}^{-1}$ in the liver, (b) $1.0 \mathrm{~mL}$ of $100 \mathrm{mg} \cdot \mathrm{L}^{-1}$ in the liver, (c) $0.5 \mathrm{~mL}$ of $100 \mathrm{mg} \cdot \mathrm{L}^{-1}$ in muscles. (d) $1.0 \mathrm{~mL}$ of $100 \mathrm{mg} \cdot \mathrm{L}^{-1}$ in muscles.

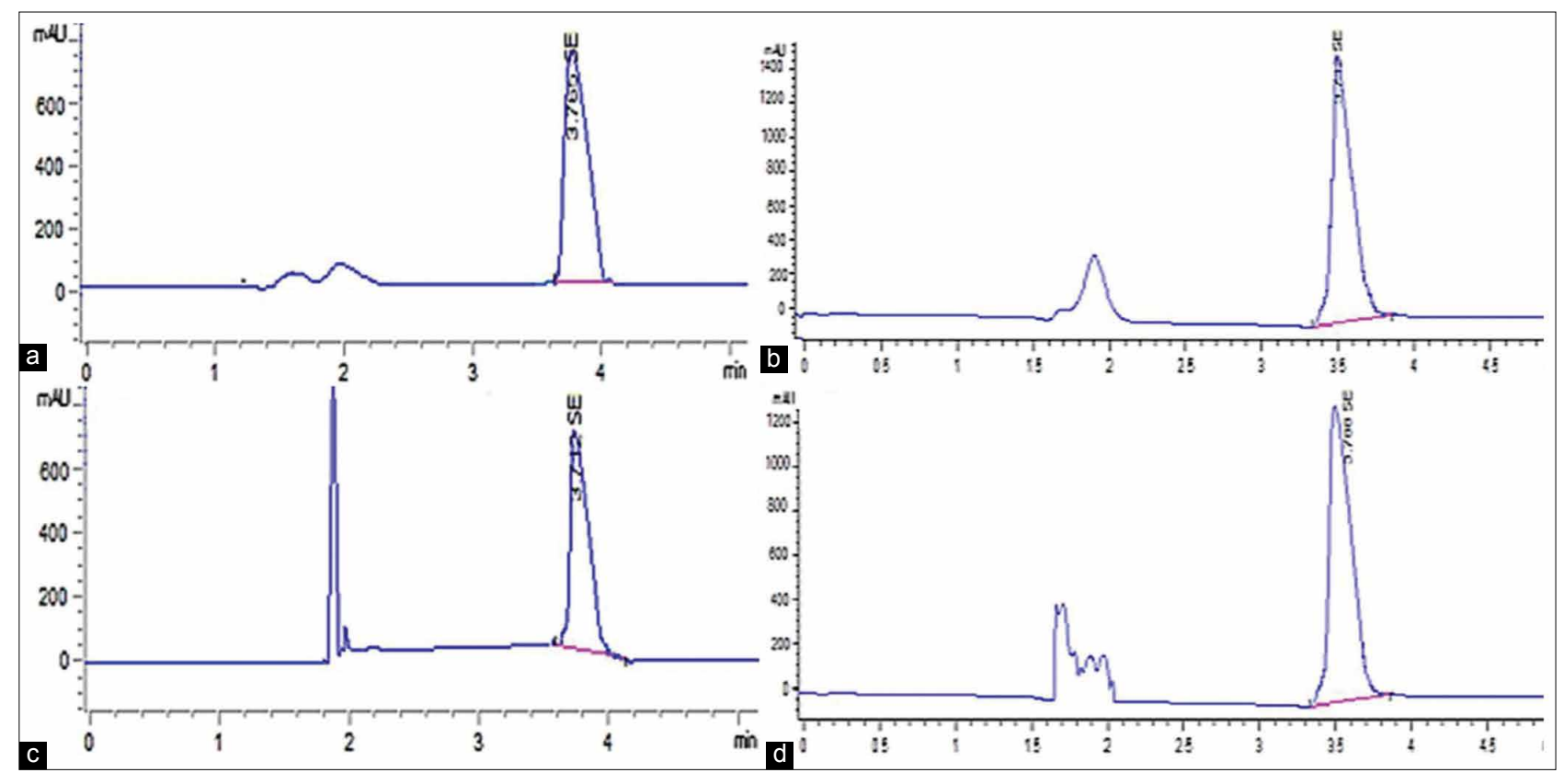

Figure-2: Liquid chromatography of selenium residues in liver and muscles at 1st day following supplementation with: (a) $0.5 \mathrm{~mL}$ of $100 \mathrm{mg} \cdot \mathrm{L}^{-1}$ in the liver, (b) $1.0 \mathrm{~mL}$ of $100 \mathrm{mg} \cdot \mathrm{L}^{-1}$ in the liver, (c) $0.5 \mathrm{~mL}$ of $100 \mathrm{mg} . \mathrm{L}^{-1}$ in muscles. (d) $1.0 \mathrm{~mL}$ of $100 \mathrm{mg} \cdot \mathrm{L}^{-1}$ in muscles.

Spleen histopathological photomicrographs in broilers supplemented with $0.5 \mathrm{~mL}$ NS (Figure-7a) showed mild lymphoid depletion with a moderate area of hemorrhage, in broilers supplemented with 1.0 $\mathrm{mL}$ NS (Figure-7b) they revealed moderate lymphoid depletion, in broilers supplemented with $0.5 \mathrm{~mL}$ inorganic Se (Figure-7c) they showed severe lymphoid depletion, and in broilers supplemented with $1.0 \mathrm{~mL}$ inorganic Se (Figure-7d) they showed an area of hemorrhage with hemosiderosis, severe congestion of splenic sinus and mild lymphoid depletion compared to normal splenic view in Figure-7e.

Tissue sections of the duodenum from control Hubbard chicken demonstrated low expression of
NF-kB p65 (Figure-8e), meanwhile, tissue sections of the duodenum from Hubbard broilers supplemented with $0.5 \mathrm{~mL}$ and $1.0 \mathrm{~mL}$ inorganic Se shown in Figure-8a and b, revealed overexpression of NF-kB p65, particularly in the nuclei of glands and epithelial cells. In contrast, the section of the duodenum from Hubbard broilers supplemented with $0.5 \mathrm{~mL}$ and 1.0 $\mathrm{mL}$ NS shown in Figure-8c and d, revealed significantly low expression of NF-kB p65 staining.

\section{Discussion}

Se is a trace element known for its important role in biological processes inside the body and in enhancing bird's performance and growth, as reported by 


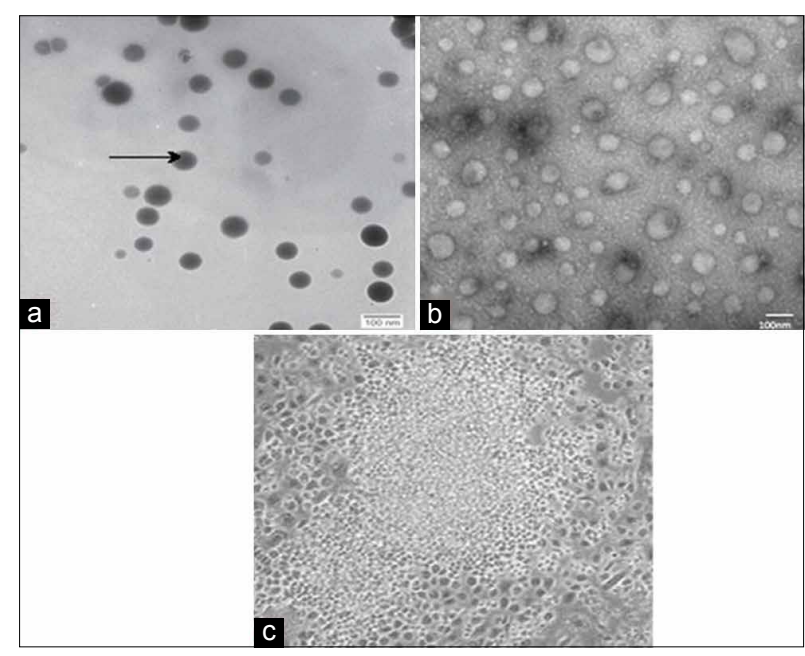

Figure-3: Scanning electron microscopy images of nanoselenium (NS) in liver samples on the 20th day. (a) The liver of broilers supplemented with $1.0 \mathrm{~mL}$ NS $\left(0.1 \mathrm{mg} . \mathrm{L}^{-1}\right)$ on the 20th day showed NS particles (arrow) of $23.8 \mathrm{~nm}$ in size and $0.0528 \mu \mathrm{g} / \mathrm{g}$ in concentration. (b) The liver of broilers supplemented with $0.5 \mathrm{~mL}$ NS $\left(0.05 \mathrm{mg} . \mathrm{L}^{-1}\right)$ on the 20th day confirmed the disappearance of NS particles. (c) The liver of un-supplemented control broilers on the 20th day. Scale bar: $100 \mathrm{~nm}$.

Lee et al. [42] and Limaye et al. [43]. Kieliszek and Błażejak [44] stated the importance of Se as micronutrients, as it helps in the protection from hydrogen peroxide, detoxification of heavy metals, enhancement of production and performance, and improvement of the immune system. Kumaran et al. [45] reported that NS revealed better improvements in growth performance compared to sodium selenite when used in the ration of Vencobb broilers. Liu et al. [46] recorded that supplementing broilers with $0.3 \mathrm{ppm}$ NS improved growth and performance over Se. Ahmadi et al. [47] reported improved performance, immunity, and carcass characteristics without any pathological alternations in organs and tissues of broilers supplemented with $0.2,0.3,0.4$, and $0.5 \mathrm{ppm}$ of NS.

Earlier studies recommended the usage of $0.5 \mathrm{~mL}$ and/or $1.0 \mathrm{~mL}$ NS or inorganic Se (100 mg. $\mathrm{L}^{-1}$ ) water supplementation in the broiler industry. Hassan et al. [12] reported significant improvements by the usage of $0.5 \mathrm{~mL} \mathrm{NS} 100 \mathrm{mg} \cdot \mathrm{L}^{-1}\left(0.05 \mathrm{mg} . \mathrm{L}^{-1}\right)$ over inorganic Se (sodium selenite) on growth traits, antioxidant activity, immunoglobulin concentration, biochemical profile, behavioral patterns, and histopathological pictures in two experimented broiler breeds (Arbor and Ross) exposed to heat stress. Meanwhile, Ali et al. [23] recommended the usage of $1 \mathrm{~mL}$ NS $100 \mathrm{mg} . \mathrm{L}^{-1}\left(0.1 \mathrm{mg} . \mathrm{L}^{-1}\right)$ and reported significant improvements of performance, behavioral patterns, antioxidant activity, immunoglobulin concentration, biochemical profile, and histopathological pictures in two experimented broiler breeds (Arbor Acres $^{\circledR}$ and $\operatorname{Ross}^{\circledR} 308$ ) exposed to the microbial challenge when comparing its influence to inorganic $\mathrm{Se}$ (sodium selenite). That is why the current study focused on conducting a comparison on the effect of different doses $(0.5$ and $1.0 \mathrm{~mL}$ at a rate of 100 $\mathrm{mg} . \mathrm{L}^{-1}$ ) of NS and inorganic Se (sodium selenite) on different parameters including growth traits, behavior, carcass characteristics, immunoglobulin concentration, intestinal bacterial load, and photomicrographs of some edible and immune organs in broiler chickens to give leverage to one of the examined doses.

The examinations and evaluations, in our study, revealed significant improvements in broilers supplemented with $0.5 \mathrm{~mL} \mathrm{NS}$ at a rate of $100 \mathrm{mg} . \mathrm{L}^{-1}$ (0.05 mg. $\left.\mathrm{L}^{-1}\right)$ compared to those supplemented with $1.0 \mathrm{~mL} \mathrm{NS}$ at a rate of $100 \mathrm{mg} . \mathrm{L}^{-1}\left(0.1 \mathrm{mg} . \mathrm{L}^{-1}\right)$ in all tested aspects. The superior influences recorded in using $0.5 \mathrm{~mL} \mathrm{NS}$ at a rate of $100 \mathrm{mg} . \mathrm{L}^{-1}\left(0.05 \mathrm{mg} . \mathrm{L}^{-1}\right)$ might be attributed to the smaller size of particles that enhanced their preventive influence. Benko et al. [48] examined the influence and toxicity of organic Se, inorganic Se, and NS on histological architecture and they revealed that NS $(100-500 \mathrm{~nm})$ was more toxic compared to organic Se (Sel-Plex and Lact-Micro Se) and inorganic Se (selenate more toxic than hydroselenite). They related the toxicity to the particle size diameter of the compound used, as larger compounds tend to be more toxic than smaller. Furthermore, Peng et al. [49] suggested using NS in a particle size diameter smaller than $100 \mathrm{~nm}$ to produce higher chemopreventive influence.

The current study revealed significant improvements in the productive performance of broilers supplemented with $0.5 \mathrm{~mL}$ rather than $1.0 \mathrm{~mL} \mathrm{NS}$ (100 mg.L $\mathrm{L}^{-1}$ ) per liter drinking water, and the results were supported by those of Saleh [50] who recorded an increase in growth performance and attributed this increase to the protein digestibility and energy utilization. Marković et al. [51] reported an enhancement in productive performance, health, immunity, egg, and meat quality in broilers under physiological stresses and supplemented with NS. Shabani et al. [52], in agreement with our results, revealed that using $200 \mu \mathrm{g}$ Se daily in broilers can enhance body WG. Zhao et al. [53] supplemented broiler breeders with 0.15 or $0.30 \mathrm{mg} / \mathrm{kg}$ Se and revealed an improvement in WG. On the contrary, the results did not agree with those of Hassan et al. [54] who used $0.3 \mathrm{mg} \mathrm{Se} / \mathrm{kg}$ for supplementing 360 50-day-old male chickens and found no significant changes in feed intakes and body WG, but there were significant improvements in antioxidant activity and carcass meat quality in these chickens.

The results also revealed significant improvements in carcass and meat quality, significant reductions in $\mathrm{pH}_{24}$, and non-significant reductions in both drip loss and water holding capacity in broilers supplemented with $0.5 \mathrm{~mL} . \mathrm{L}^{-1}$ drinking water NS in agreement with Visha et al. [55] who supplemented broilers with $0.3 \mathrm{mg}$ sodium selenite $/ \mathrm{kg}, 0.3 \mathrm{mg}$ organic $\mathrm{Se} / \mathrm{kg}$, and NS at three levels $(0.15,0.3$, and $0.6 \mathrm{mg} / \mathrm{kg})$. They revealed that broilers supplemented with NS showed a significant reduction in breast muscle drip losses 


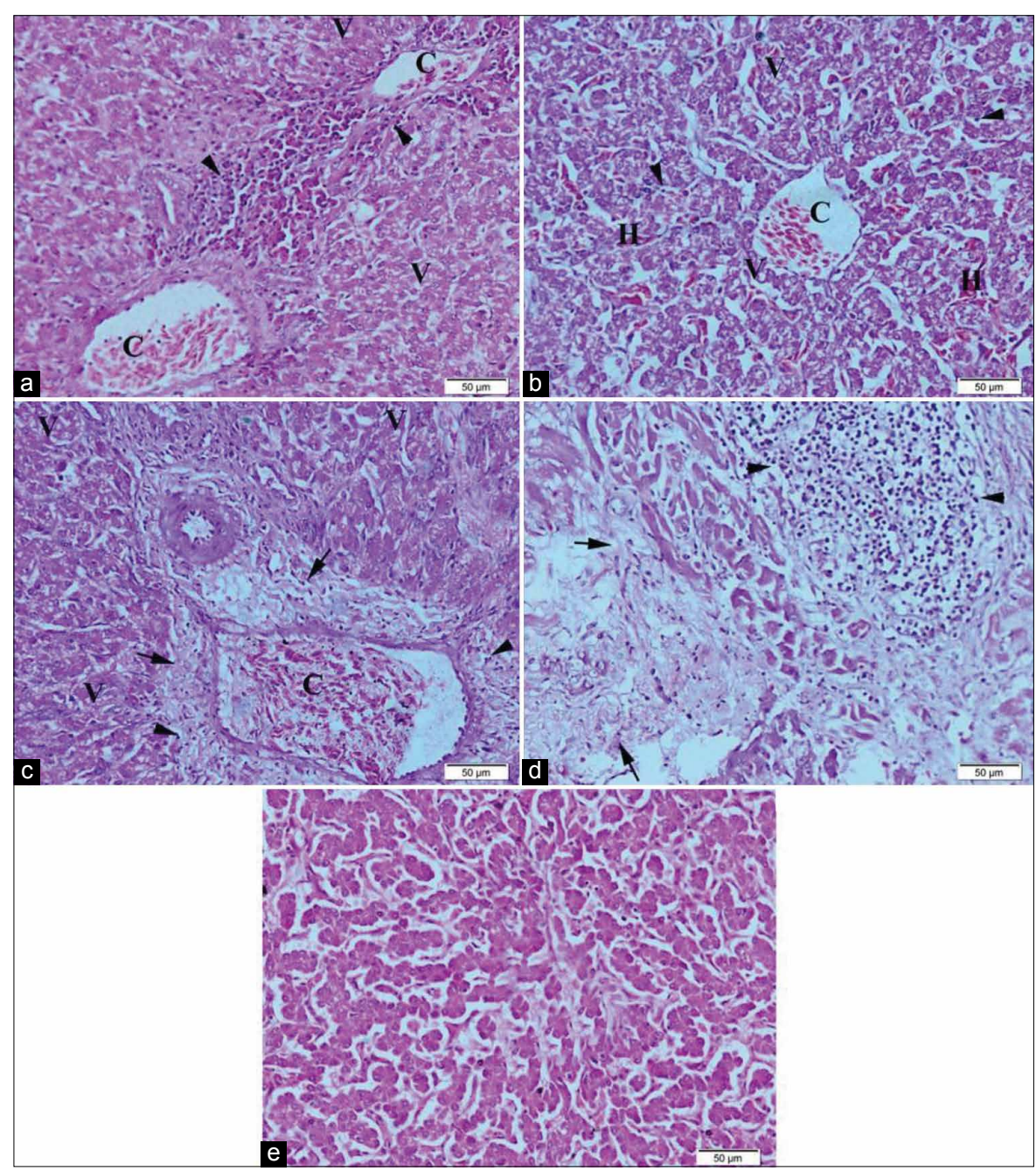

Figure-4: Representative photomicrographs of liver histopathology (20x): (a) The liver of Hubbard chicken after oral administration of $0.5 \mathrm{~mL}$ nano-selenium (NS) showing congestion of blood vessels (C), mononuclear cell infiltration (arrowhead), vaculation of hepatocytes cytoplasm (V). (b) The liver of Hubbard chicken after oral administration of 1.0 $\mathrm{mL}$ NS showing congestion of central vein, hemorrhage $(\mathrm{H})$, and vaculation of hepatocytes(V). (c) Liver of Hubbard chicken after oral administration of $0.5 \mathrm{~mL}$ selenium (Se) showing congestion of portal blood vessels (C), mononuclear cell infiltration (arrowhead), vaculation of hepatocytes cytoplasm (V), and fibrosis (arrow). (d) Liver of Hubbard chicken after oral administration of $1.0 \mathrm{~mL}$ Se. (e) The liver of control Hubbard. Hematoxylin and eosin. Bar $50 \mu \mathrm{m}$.

and lipid peroxidation. They recommended a dose of $0.3-0.6 \mathrm{mg} \mathrm{NS} / \mathrm{kg}$ ration for broilers to minimize drip losses and lipid peroxidation to enhance meat quality. Our results were in agreement with those of Yang et al. [56] who recorded that supplementary Se different forms did not influence the $\mathrm{pH}$ values of breast meat. In agreement with our results, Surai et al. [57] recorded a lower drip loss in broilers supplemented with $0.3-0.6 \mathrm{mg} / \mathrm{kg}$ NS. Li et al. [58] reported as well that broilers supplemented with $0.15 \mathrm{mg} / \mathrm{kg}$ NS had a significantly lower drip loss in the breast muscle at 24 and $48 \mathrm{~h}$ after slaughter.

Supplementing Hubbard broilers in the current study with 0.5 and $1.0 \mathrm{~mL}$ NS were able to significantly improve $\operatorname{IgG}$ and $\mathrm{M}$ concentrations with a higher degree of increase in broilers supplemented with $0.5 \mathrm{~mL} . \mathrm{L}^{-1}$ drinking water. The results were consonant with those of Cai et al. [59] who used NS at a rate of $0.0,0.3,0.5,1.0$, or $2.0 \mathrm{mg} / \mathrm{kg}$ in 1-dayold Arbor broilers, they stated significant increase in the glutathione activity, malondialdehyde formation, and IgM concentrations. They also recommended 0.3:0.5 mg NS/ $/ \mathrm{kg}$ as optimum supplementation levels with $1.0 \mathrm{mg} \mathrm{NS} / \mathrm{kg}$ as maximum supplementation levels in broilers. Bakhshalinejad et al. [60] also supplemented broilers with $0.4 \mathrm{mg} / \mathrm{kg}$ NS for 1-day-old male Ross broilers and revealed significant enhancements in IgG concentrations. Xiao et al. [61] and Gulyas et al. [62] also recorded significant increases of immunoglobulin concentration in broilers supplemented with NS and they attributed the increase in the immunoglobulin levels to the enhancing influence of NS on protein synthesis and through increasing the eukaryotic translation initiation factor 5A-1, which contributed in the increase of protein synthesis, and thus increased IgG and $\mathrm{M}$ concentrations. Da Silva et al. [63] in synchronization with the current results reported that organic forms of Se significantly decreased antibody titer through the action on tissue and organ integrity and the enhancement in the metabolic rates. Boostani et al. [64] conducted a randomized trial to compare the influence of organic Se $\left(\mathrm{Sel}-\mathrm{Plex}{ }^{\circledR}\right)$, inorganic Se 


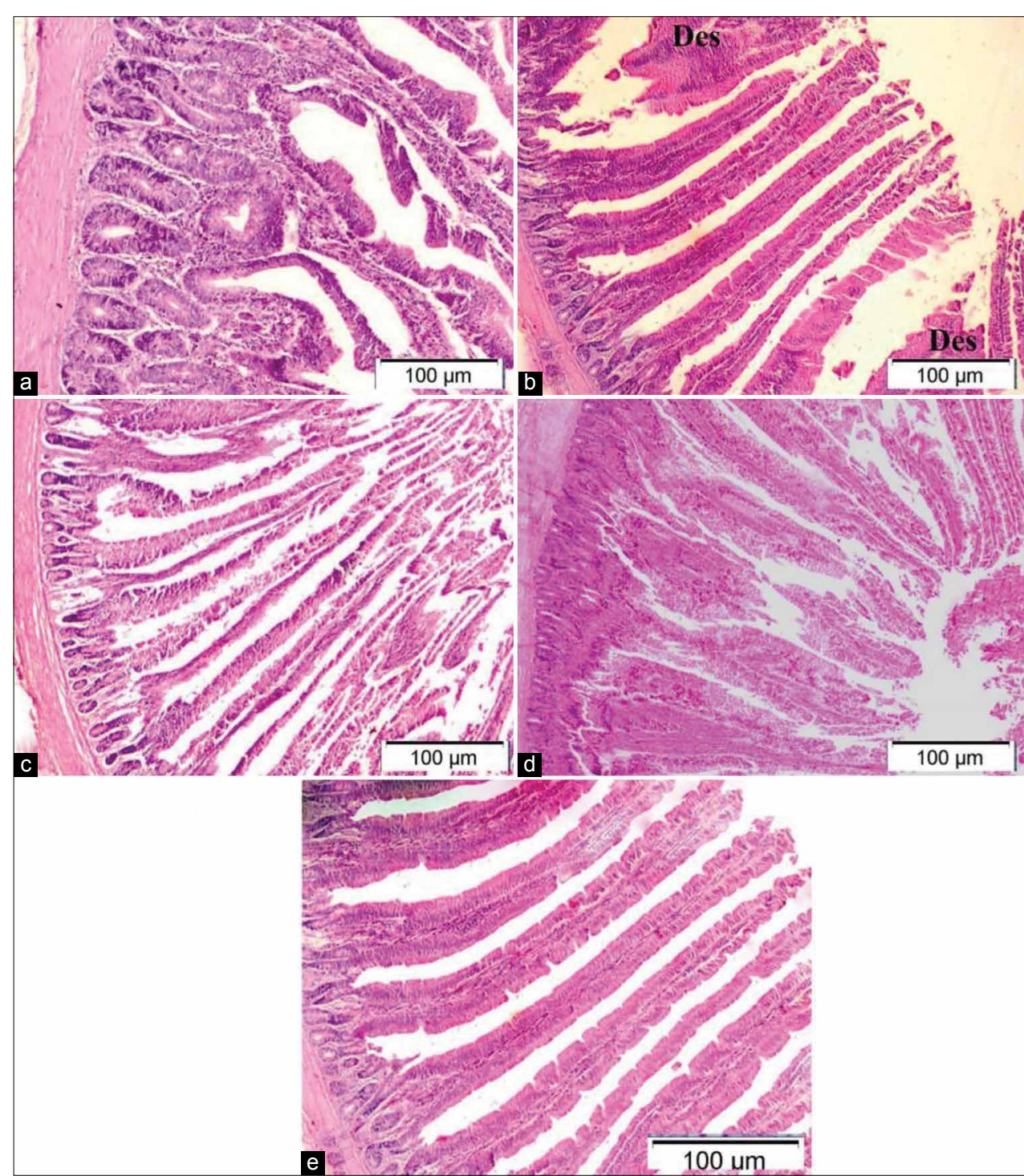

Figure-5: Representative photomicrographs of duodenum histopathology (10x): (a) Duodenum of Hubbard chicken after oral administration of $0.5 \mathrm{~mL}$ nano-selenium (NS). (b) Duodenum of Hubbard chicken after oral administration of $1.0 \mathrm{~mL}$ NS showing mild desquamation of villi (des). (c) Duodenum of Hubbard chicken after oral administration of $0.5 \mathrm{~mL}$ selenium (Se). (d) Duodenum of Hubbard chicken after oral administration of $1.0 \mathrm{~mL} \mathrm{Se}$. (e) Duodenum of control Hubbard. Hematoxylin and eosin. Bar $100 \mu \mathrm{m}$.

(sodium selenite), and NS (10:45 $\mathrm{nm}, 99.95 \%$ purity) in a rate of $0.3 \mathrm{mg} / \mathrm{kg}$ diet on 320 male $\mathrm{Cobb}^{\circledR} 500$ broilers in the presence and absence of oxidative stress, they recorded significant increases of $\mathrm{IgG}$ and IgM serum concentrations in broilers supplemented with NS compared to birds supplemented with Se in the presence of oxidative stresses.

Hubbard broilers in our study supplemented with $0.5 \mathrm{~mL} . \mathrm{L}^{-1}$ drinking water NS revealed significant reductions in TBC and TEC rather than $1.0 \mathrm{~mL}$ NS and commercial Se supplementation. The results were supported by those of Barko et al. [65] who revealed that NS stimulate and encourage intestinal normal inhabitant to compete directly against opportunistic and pathogenic microorganisms for their receptor sites and prevent their growth and multiplication. Moreover, NS raised the level of specific immunity that contributed in a significant decline in total bacterial and TEC s. Gangadoo et al. [66], in agreement with our results, found that using NS in poultry might have direct antibacterial actions against pathogens as E. coli. Stanley et al. [67] recorded significant antimicrobial activities of NS against $E$. coli. Yip et al. [68] also in agreement confirmed the antimicrobial activity of NS against bacterial microorganisms such as E. coli and fungal organisms such as Trichophyton rubrum. Kheradmand et al. [69] recorded the antimicrobial action of NS against bacterial microorganisms such as Pseudomonas aeruginosa and fungal organisms such as Candida albicans. Shakibaie et al. [70] also recorded the antimicrobial actions of NS against Proteus mirabilis.

NS has gained much attraction for many reasons like its high bioavailability and low toxicity. The current study focused on more interest in the withdrawal time of the Se and NS from broilers' organs and tissues. Thus the study revealed longer persistence of inorganic Se (sodium selenite) in broiler muscles and liver 


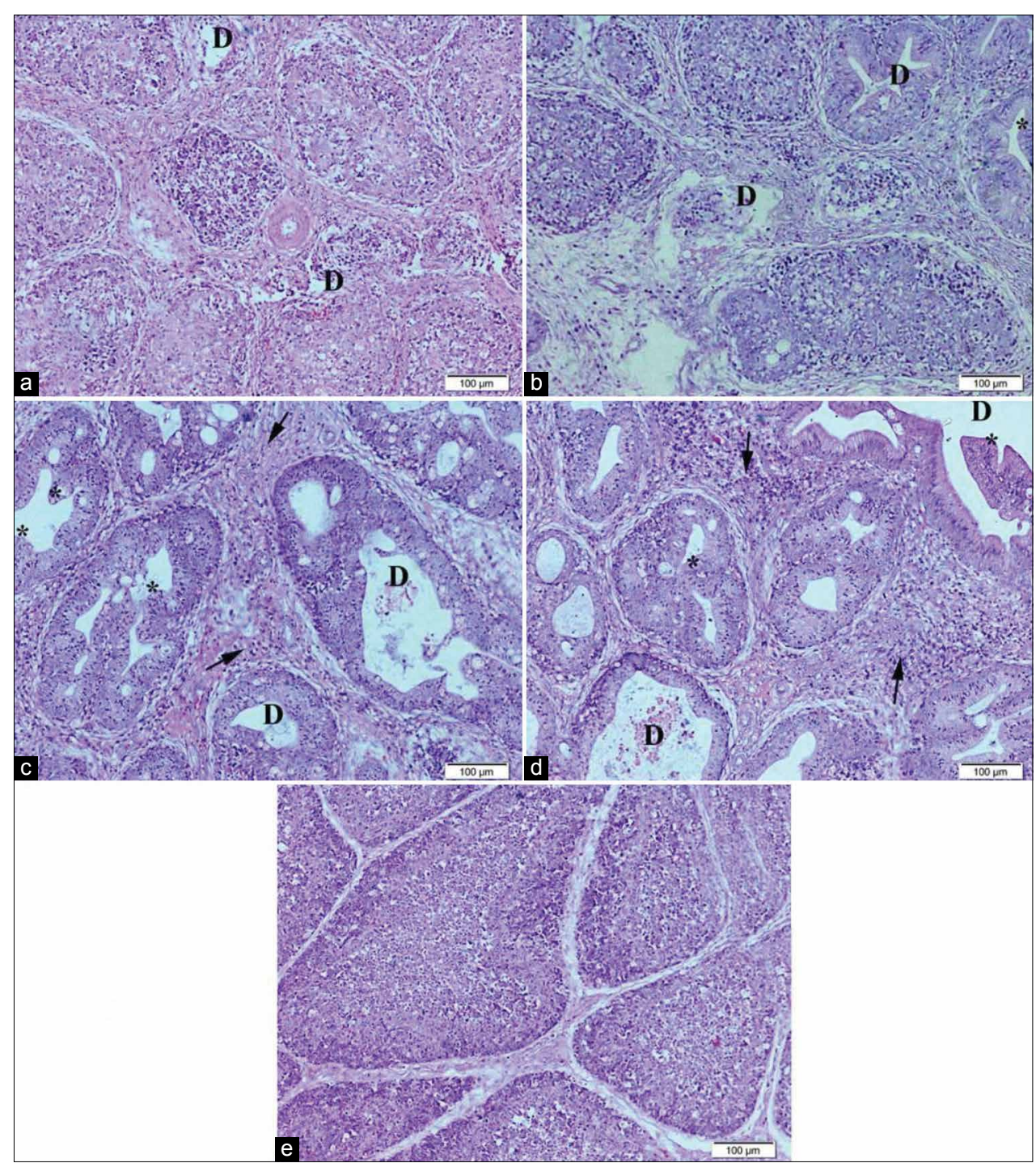

Figure-6: Representative photomicrographs of bursa histopathology (10x): (a) Bursa of Hubbard chicken supplemented with $0.5 \mathrm{~mL}$ nano-selenium (NS) showing mild depletion of lymphocytes (D). (b) Bursa of Hubbard chicken supplemented with $1.0 \mathrm{~mL}$ NS showing mild depletion of lymphocytes (D) and hyperplasia of follicular epithelium (*). (C) Bursa of Hubbard chicken supplemented with $0.5 \mathrm{~mL}$ selenium (Se) showing severe depletion of lymphocytes (D) hyperplasia of follicular epithelium (*) and increased interfollicular fibrosis (arrow). (d) Bursa of Hubbard chicken supplemented with 1.0 $\mathrm{mL}$ Se. (e) Bursa of control Hubbard. Hematoxylin and eosin. Bar $100 \mu \mathrm{m}$.

compared to NS. Electron microscopy images showed the disappearance of NS from the liver of broiler supplemented with $0.5 \mathrm{~mL} \mathrm{NS}\left(0.05 \mathrm{mg} . \mathrm{L}^{-1}\right)$ and its presence in the liver of broiler supplemented with $1.0 \mathrm{~mL}$ NS $\left(0.1 \mathrm{mg} . \mathrm{L}^{-1}\right)$ by the $20^{\text {th }}$ day. RP-HPLC showed that sodium selenite $(0.5$ and $1.0 \mathrm{~mL})$ was detectable in both liver and muscles up to the $45^{\text {th }}$-day post-sacrificing, $0.5 \mathrm{~mL} \mathrm{NS}$ disappeared in muscles at the $20^{\text {th }}$ day and in liver at the $30^{\text {th }}$-day, and $1.0 \mathrm{~mL}$ NS disappeared in muscles at $30^{\text {th }}$ day and in liver at $35^{\text {th }}$-day post-sacrificing. Mohapatra et al. [71] studied the influence of NS and inorganic Se (sodium selenite) in a rate of $0.3 \mathrm{mg} / \mathrm{kg}$ diet on Se bioavailability and deposition in the liver, breast muscles, pancreas, kidney, feathers, spleen, bursa of Fabricius, and thymus of 300 layer chicks up to $8^{\text {th }}$ week; they reported that Se contents in the organs and tissues under-study were significantly increased in broilers supplemented with NS rather than in inorganic Se. Wang [72] reported that
NS could serve as another Se form and successfully improved tissue Se content of avian broilers compared with the control group. The current results confirmed that NS tissue residues disappeared earlier in the liver and muscles compared to Se residues that persist up to $45^{\text {th }}$-day samples. Similar results were recorded by Pan et al. [73] who found that liver, kidney, spleen, breast muscles, and whole-body Se concentrations in Rohman laying hens were higher in the groups given Se. Diskin et al. [74] and $\mathrm{Hu}$ et al. [75] reported a higher Se content in the liver than in muscle across all treatments. According to FSANZ [76], the limit of reporting (LOR) for Se was $0.01 \mathrm{mg} / \mathrm{kg}$, which is convenient with NS in the current results rather than Se where the detected residues in both doses of Se were above the LOR. NHMRC [77] also reported that the recommended dietary intake (RDI) of Se for all subpopulations should not exceed $0.00179 \mathrm{mg} / \mathrm{kg}$; so, the results of NS in the current study were below 


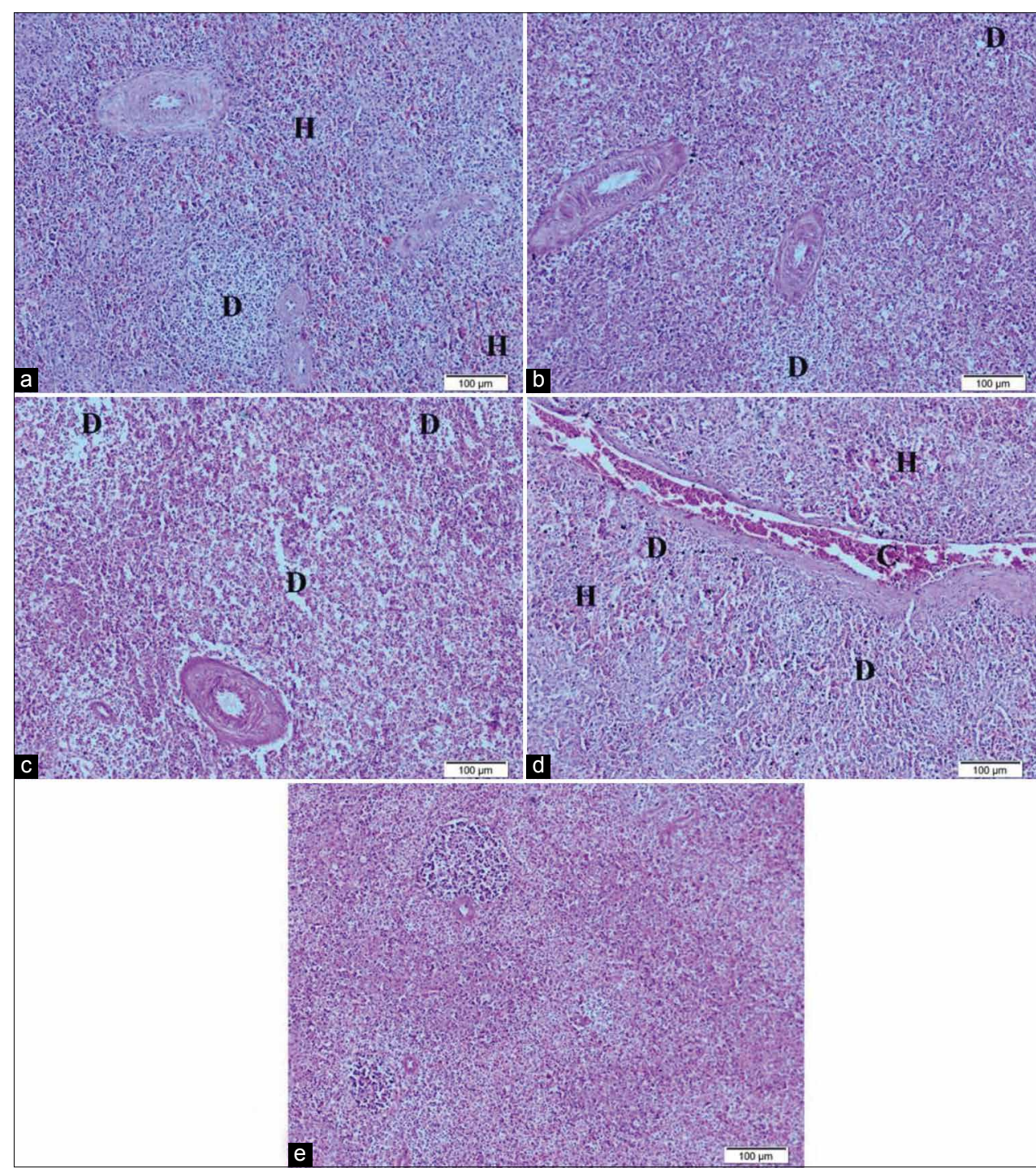

Figure-7: Representative photomicrographs of spleen histopathology (10x): (a) Spleen of Hubbard chicken after oral administration of $0.5 \mathrm{~mL}$ nano-selenium (NS) showing depletion of lymphocytes (D) and mild hemorrhage (H). (b) The spleen of Hubbard chicken after oral administration of $1.0 \mathrm{~mL}$ NS. (c) The spleen of Hubbard chicken after oral administration of $0.5 \mathrm{~mL}$ selenium (Se). (d) The spleen of Hubbard chicken after oral administration of $1.0 \mathrm{~mL}$ Se showing depletion of lymphocytes (D), hemorrhage, and severe congestion of splenic sinus (C). (e) The spleen of control Hubbard chicken Hematoxylin and eosin. Bar $100 \mu \mathrm{m}$.

RDI within the two doses. The early disappearance of NS from liver and muscles compared to inorganic Se might be contributed to the nano-particles size $(25 \mathrm{~nm})$ and the characterizations that ensured minimum or no pathological affection in broilers supplemented with lower doses $\left(0.5 \mathrm{~mL} 100 \mathrm{mg} . \mathrm{L}^{-1}\right.$ equivalents to $0.05 \mathrm{mg} . \mathrm{L}^{-1}$ drinking water). Gandadoo et al. [78], Gangadoo et al. [66], and Shi et al. [79] confirmed that NS particles showed enhanced absorption, bioavailability, and rapid excretion from the body contributing less negative effect on tissues and organs.

Histopathological photomicrographs of the liver, spleen, bursa of Fabricius, and intestine, as well as immunohistochemistry photomicrographs of the duodenum in the current study, revealed enhanced and nearly normal tissue architecture in broilers supplemented with NS $(0.5$ and $1.0 \mathrm{~mL})$ compared to broilers supplemented with Se and to un-supplemented control broilers even in the presence of $E$. coli infection.
The recorded enhancement was consistent with those recorded by Alkhudhayri et al. [80] who reported improved histological tissue architecture from NS supplementation in the presence of some overwhelming challenges as E. coli infection. Mousa and Ali [81] also reported the enhanced influence of nanoparticles on the liver cellular architecture in face of $E$. coli infection in Africa ostrich chicks as well as the increased levels of resistance in the birds. The current results were also consistent with those recorded by Selim et al. [82] who recorded some adverse influences in liver histopathology such as inflammation and necrosis from supplementing broilers with higher doses of NS or Se compared to the influence of lower levels. The results also stated that Se-Yeast or Zn-Se-Meth produced higher levels of liver tissue safety. Attia et al. [83] also evaluated the influence of sodium selenite (inorganic Se) and Selplex (organic Se) at levels of 0.15 and $0.30 \mathrm{ppm}$ compared to NS on the productive performance of Egyptian 

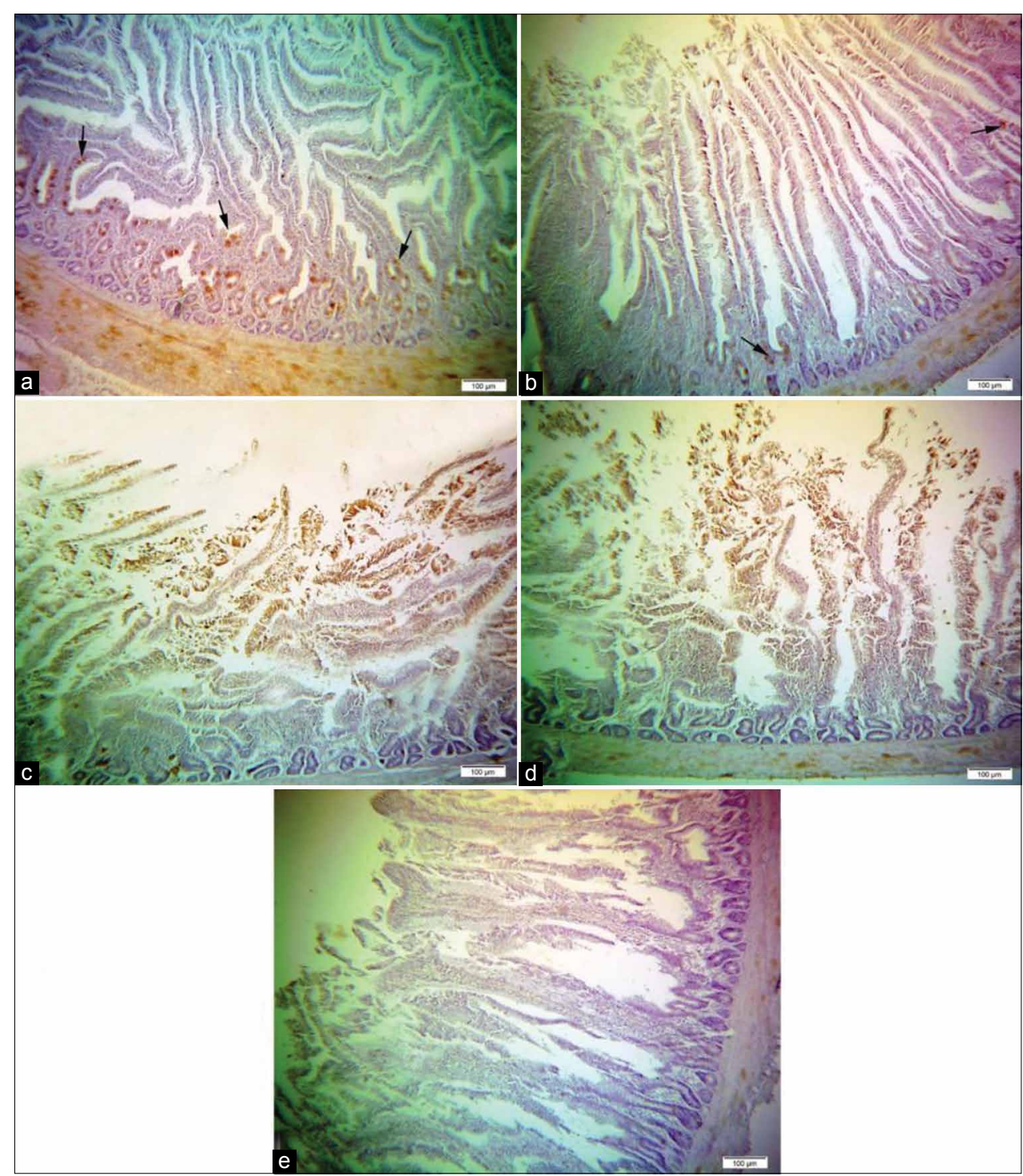

Figure-8: Immunohistochemical detection of phospho-nuclear factor kappa B (NF-KB) p65 in the duodenum of Hubbard chicken; (a) duodenum of Hubbard chicken after oral administration of $0.5 \mathrm{~mL}$ nano-selenium (NS). (b) Duodenum of Hubbard chicken after oral administration of $1.0 \mathrm{~mL}$ NS. (c) Duodenum of Hubbard chicken after oral administration of $0.5 \mathrm{~mL}$ selenium (Se). (d) Duodenum of Hubbard chicken after oral administration of $1.0 \mathrm{~mL}$ Se. (e) Duodenum of control Hubbard. Arrows refer to phospho-NF-KB p65 expression, which positively stained brown in the nuclei of glands and epithelial cells. $(10 \times)$ Bar $100 \mu \mathrm{m}$

chicken strain (Gimmizah). They recorded mild influences produced by either NS or organic Se on hepatic tissues compared to inorganic Se.

\section{Conclusion}

NS supplementation in Hubbard broilers revealed significant improvements in the productive performance, carcass quality, meat quality, and immunoglobulin concentration, as well as a significant antibacterial action regarding the usage of $0.5 \mathrm{~mL} \mathrm{NS}$ at a rate of $100 \mathrm{mg} / \mathrm{L}$ NS $\left(0.05 \mathrm{mg} . \mathrm{L}^{-1}\right)$. The recorded enhanced measurements were aligned with determining zero residues in muscles and edible organs as well as, greater improvement in tissues and organs architecture.

\section{Authors' Contributions}

ESS designed the experimental design, supervised, and participated in the preparation and execution of the experiment, and in writing the manuscript. FFM conducted carcass quality parameters, $\mathrm{pH}$ and drip losses, and participated in writing the manuscript. MAF conducted HPLC and EM examination in liver and muscle samples and participated in writing the manuscript. RTH conducted the histopathological and immunohistochemistry examination and participated in writing the manuscript.

\section{Acknowledgments}

The authors are thankful to Dr. O.M. Abdelmoniem, Nano Science and Technology Institute, Kafr El-Sheikh University, Kafr El-Sheikh, Egypt, for supplying NS voluntarily. The authors are also thankful to Prof. M.A. Sobieh for his tremendous directions during the execution of the experiment. The authors did not receive any funds for this study. 


\section{Competing Interests} interests.

The authors declare that they have no competing

\section{Publisher's Note}

Veterinary World remains neutral with regard to jurisdictional claims in published institutional affiliation

\section{References}

1. Yaqoop, P. (2017) Impact of probiotics on the immune response to influenza vaccination is strongly influenced by ageing. Nutr. Bull., 42(1): 87-93.

2. $\quad$ Plaza-Diaz, J., Ruiz-Ojeda, F.J., Gil-Capos, M. and Gil, A. (2018) Immune-mediated mechanisms of action of probiotics and synbiotics in treating pediatric intestinal diseases. Nutrients, 10(1): 42.

3. Soliman, E.S., Hamad, R.T. and Ahmed, A. (2017) Prophylactic and immune-modulatory influences of Nigella sativa Linn. In broilers exposed to biological challenge. Vet. World, 10(12): 1447-1455.

4. Yang, X., Long, F., Xin, H., Yang, C. and Yang, X. (2018) Impact of essential oils and organic acids on the growth performance, digestive functions and immunity of broiler chickens. Anim. Nutr., 4(4): 388-393.

5. Pan, T., Liu, T., Tan, S., Wan, N., Zhang, Y. and Li, S. (2018) Lower selenoprotein $\mathrm{T}$ expression and immune response in the immune organs of broilers with exudative diathesis due to selenium deficiency. Biol. Trace Elem. Res., 182(2): 364-372.

6. Markovic, R., Cirić, J., Starčević, M., Šefer, D. and Baltić, M.Z. (2018) Effect of selenium source and level in diet on glutathione peroxidase activity, tissue selenium distribution, and growth performance in poultry. Anim. Health Res. Rev., 19(2): 166-176.

7. Mohanty, P.P., Panda, N., Swain, R.K., Behura, N.C., Ray, P., Sethi, A.K. and Panigrahi, S. (2018) A comparison between organic and inorganic selenium: 1. effect on bodyweight, laying performance, hatchability in broiler breeder. Int. J. Curr. Microbiol. Appl. Sci., 7(5): 173-179.

8. Oliveira, T.F.B., Rivera, D.F.R., Mesquita, F.R., Braga, H., Ramos, E.M. and Bertechini, A.G. (2014) Effect of different sources and levels of selenium on performance, meat quality, and tissue characteristics of broilers. J. Appl. Poult. Res., 23(1): 15-22.

9. Amoako, P.O., Uden, P.C. and Tyson, J.F. (2009) Speciation of selenium dietary supplements; formation of S-(methylseleno) cysteine and other selenium compounds. Anal. Chim. Acta, 652(1-2): 315-323.

10. Wadhwani, S.A., Shedbalkar, U.U., Singh, R. and Chopade, B.A. (2016) Biogenic selenium nanoparticles: Current status and future prospects. Appl. Microbiol. Biotech., 100(6): 2555-2566.

11. Skalickova, S., Milosavljevic, V., Cihalova, K., Horky, P., Richtera, L. and Adam, V. (2017) Selenium nanoparticles as a nutritional supplement. Nutrition, 33(January): 83-90.

12. Hassan, R.A., Soliman, E.S., Hamad, R.T., El-Borady, O.M., Ali, A.A., Helal, M.S. (2020) Selenium and nano-selenium ameliorations in two breeds of broiler chickens exposed to heat stress. South Afr. J. Anim. Sci., 50(2): 215-232.

13. Rajashree, K., Muthukumar, T. and Karthikeyan, N. (2014) Comparative study of the effects of organic selenium on hen performance and productivity of broiler breeders. Br. Poult. Sci., 55(3): 367-374.

14. Mahima, Verma, A.K., Kumar, A., Rahal, A., Kumar, V. and Roy, D. (2012) Inorganic selenium supplementation: A review. Pak. J. Biol. Sci., 15(9): 418-425.

15. Thammana, M. (2016) A review on high-performance liquid chromatography (HPLC). RRJPA, 5(2): 22-28.
16. Gratzfeld-Hüsgen, A. and Schuster, R. (2001) HPLC for Food Analysis. A Primer. Agilent Technologies Company, Germany. p4-5.

17. Li, Y.F., Hu, L., Li, B., Huang, X., Larsen, E.H., Gao, Y. and Chen, C. (2011) Full quantification of selenium species by $\mathrm{RP}$ and AF-ICP-q MS with on-line isotope dilution in serum samples from mercury-exposed people supplemented with selenium-enriched yeast. J. Ana. Atomic Spectro., 26(1): 224-229.

18. Soliman, E.S., Sallam, N.H. and Abouelhassan, E.M. (2018) Effectiveness of poultry litter amendments on bacterial survival and Eimeria oocyst sporulation. Vet. World, 11(8): 1064-1073.

19. Soliman, E.S. and Hassan, R.A. (2019) Impact of lighting color and duration on productive performance and Newcastle disease vaccination efficiency in broiler chickens. Vet. World, 12(7): 1052-1059.

20. National Research Council. (1994) Nutrient Requirements for Poultry. $9^{\text {th }}$ ed. National Research Council, New York.

21. Applegate, T.J. and Angel, R. (2014) Nutrient requirements of poultry publication: History and need for an update. $J$. Appl. Poult. Res., 23(3): 567-575.

22. Gorer, S. and Hodes, G. (1994) Quantum size effects in the study of chemical solution deposition mechanisms of semiconductor films. J. Phys. Chem., 98(20): 5338-5346.

23. Ali, A.A., Soliman, E.S., Hamad, R.T., El-Borady, O.M., Hassan, R.A. and Helal, M.S. (2020) Preventive, behavioral, productive, and tissue modification using green synthesized selenium nanoparticles in the drinking water of two broilers breeds under microbial stress. Rev. Bras. Ciênc. Avic., 22(1).

24. Herigstad, B., Hamilton, M. and Heersink, J. (2001) How to optimize the drop plate method for enumerating Bacteria. $J$. Microbiol. Meth., 44(2): 121-129.

25. Kocijancic, D., Felgner, S., Frahm, M., Komoll, R.M., Iljazovic, A., Pawar, V., Rohde, M., Heise, U., Zimmermann, K., Gunzer, F., Hammer, J., Crull, K., Leschner, S. and Weiss, S. (2016) Therapy of solid tumors using probiotic symbioflor-2-restraints and potential. Oncotarget, 7(16): 22605-22622.

26. Thrusfield, M. (2005) Veterinary Epidemiology. $3^{\text {rd }}$ ed. Wiley Blackwell, Oxford. p228-330.

27. Soliman, E.S. and Hassan, R.A. (2017) Evaluation of superphosphate and meta-bisulfide efficiency in litter treatment on productive performance and immunity of broilers exposed to ammonia stress. Adv. Anim. Vet. Sci., 5(6): 253-259.

28. Zhou, X. and Wang, Y. (2011) Influence of dietary nano elemental selenium on growth performance, tissue selenium distribution, meat quality, and glutathione peroxidase activity in Guangxi yellow chicken. Poult. Sci., 90(3): 680-686.

29. Zhuang, H., Savage, E.M., Smith, D.P. and Berrang, M.E. (2008) Effect of dry-air chilling on Warner-Bratzler shear force and water-holding capacity of broiler breast meat deboned four hours postmortem. Int. J. Poult. Sci., 7(8): 743-748.

30. Fadel, M.A., Mahmoud, F.F. and Soliman, E.S. (2019) Validation of HPLC methods for detection of selenium and nano-selenium in chicken tissues. Anim. Health Res., 7(1): 227-237.

31. Mühlfeld, C., Rothen-Rutishauser, B., Vanhecke, D., Blank, F., Gehr, P. and Ochs, M. (2007) Visualization and quantitative analysis of nanoparticles in the respiratory tract by transmission electron microscopy. Part. Fibre Toxicol., 4(1): 11.

32. Wu, Y.N., Yan, F.F., Hu, J.Y., Chen, H., Tucker, C.M., Green, A.R. and Cheng, H.W. (2017) The effect of chronic ammonia exposure on acute-phase proteins, immunoglobulin, and cytokines in laying hens. Poult. Sci., 96(6): 1524-1530.

33. American Public Health Association, American Water Works Association, Water Environment Federation. (2012) 
Standard Methods for the Examination of Water and Wastewater. 22 $2^{\text {th }}$ ed. American Water Work Association Publications, Washington D.C.

34. Kim, S.K. and Lee, J.H. (2016) Biofilm modeling systems. Korean J. Microbiol., 52(2): 125-139.

35. Soliman, E.S., Moawed, S.A. and Ziaan, A.M.G. (2016) Assessing cleaning and disinfection regime in a slaughterhouse against carcasses contamination. Adv. Anim. Vet. Sci., 4(9): 449-457.

36. Murray, P.R., Rosenthal, K.S. and Pfaller, M.A. (2015) Medical Microbiology. $8^{\text {th }}$ ed. Elsevier Health Sciences, Philadelphia, PA, USA.

37. Bancroff, J., Stevenes, A. and Turner, D. (1990) Theory and Practice of Histological Techniques. $3^{\text {rd }}$ ed. Clurechill Livingston, Edinburgh, London.

38. Jones, M.L., Bancroft, J.D. and Gamble, M. (2008) Connective tissues and stains. In: Bancroft, J.D. and Gamble, M., editors. Theory and Practice of Histological Techniques. Churchill Livingstone Elsevier, Philadelphia, PA. p135-160.

39. Eissa, S. and Shoman, S. (1998) Markers of invasion and metastasis and markers of tumor proliferation and apoptosis. In: Tumors Markers. Chapman and Hall, Lippincott Raven Publisher Inc., London, UK. p131-153.

40. Hsu, S.M., Raine, L. and Fanger, H. (1980) Use of avidin-biotin-peroxidase complex (ABC) in immunoperoxidase techniques: A comparison between $\mathrm{ABC}$ and unlabeled antibody (PAP) procedures. J. Histochem. Cytochem., 29(4):577-580.

41. SPSS. (2016) Statistical Packages of Social Sciences. Version 21 for Windows. SPSS, Inc., United States.

42. Lee, J.M., Chun, H.J., Choi, H.S., Kim, E.S., Seo, Y.S., Jeen, Y.T., Lee, H.S., Um, S.H., Kim, C.H. and Sul, D. (2017) Selenium administration attenuates 5-flurouracil-induced intestinal mucositis. Nutr. Cancer, 69(4): 616-622.

43. Limaye, A., Yu, R.C., Chou, C.C., Liu, J.R. and Cheng, K.C. (2018) Protective and detoxifying effects conferred by dietary selenium and curcumin against AFB1-mediated toxicity in livestock: A Review. Toxins, 10(1): 25.

44. Kieliszek, M. and Błażejak, S. (2016) Current knowledge on the importance of selenium in food for living organisms: A review. Molecules, 21(5): 609.

45. Kumaran, S.C., Sugapriya, S., Manivannan, N. and Shekar, C. (2015) Effect on the growth performance of broiler chickens by selenium nanoparticles supplementation. Int. Res. J. Nano Sci. Technol., 5(4-6): 161-168.

46. Liu, S., Tan, H., Wei, S., Zhao, J., Yang, L., Li, S., Zhong, C., Yin, Y., Chen, Y. and Peng, Y. (2015) Effect of selenium sources on growth performance and tissue selenium retention in yellow broiler chicks. J. Appl. Anim. Res., 43(4): 487-490.

47. Ahmadi, M., Ahmadian, A. and Seidavi, A.R. (2018) Effect of different levels of nano-selenium on performance, blood parameters, immunity and carcass characteristics of broiler chickens. Poult. Sci. J., 6(1): 99-108.

48. Benko, L., Nagy, Y.G., Tanczos, Z.B., Ungvari, Z.E., Sztrikand, Y.A. and Eszenyi, P. (2012) Subacute toxicity of nano-selenium compared to other selenium species in mice. Environm. Toxicol. Chem., 31(12): 2812-2820.

49. Peng, D., Zhang, J., Liu, Q. and Taylor, E.W. (2007) Size effect of elemental selenium nanoparticles (nano-se) at supranutritional levels on selenium accumulation and glutathione S-transferase activity. J. Inorg. Biochem., 101(10): 1457-1463.

50. Saleh, A.A. (2014) Effect of dietary mixture of Aspergillus probiotic and selenium nano-particles on growth, nutrient digestibilities, selected blood parameters and muscle fatty acid profile in broiler chickens. Anim. Sci. Pap. Rep., 32(1): 65-79.

51. Marković, R., Glišić, M., Bošković, M. and Baltić, M.Ž. (2017) New scientific challenges-the possibilities of using selenium in poultry nutrition and impact on meat quality.
IOP Conf. Series Earth Environ. Sci., 85(1): 012032.

52. Shabani, A., Noshadian, M., Jamilian, M., Chamani, M., Mohammadi, S. and Asemi, Z. (2018) The effects of a novel combination of selenium and probiotic on weight loss, glycemic control and markers of cardio-metabolic risk in women with polycystic ovary syndrome. J. Funct. Foods, 46(July 2018): 329-334.

53. Zhao, R., Li, K., Wang, J., Wang, Y., Wu, R. and Zhan, X. (2018) Effects of different forms and levels of selenomethionine on productive performance and antioxidant status of broiler breeders and its offspring. Biol. Trace Elem. Res., 188(1): 1-7.

54. Hassan, S., Hassan, F. and Rehman, M.S. (2020) Nanoparticles of trace minerals in poultry nutrition: Potential applications and future prospective. Biol. Trace Elem. Res., 195(2): 591-612.

55. Visha, P., Nanjappan, K., Selvaraj, P., Jayachandran, S. and Thavasiappan, V. (2017). Influence of dietary nanoselenium supplementation on the meat characteristics of broiler chickens. Int. J. Curr. Microbiol. Appl. Sci., 6(5): 340-347.

56. Yang, Y.R., Meng, F.C., Wang, P., Jiang, Y.B., Yin, Q.Q., Chang, J., Zuo, R.Y., Zheng, Q.H. and Liu, J.X. (2012) Effect of organic and inorganic selenium supplementation on growth performance, meat quality and antioxidant property of broilers. Afr. J. Biotechnol., 11(12): 3031-3036.

57. Surai, P.F., Kochisk, I.I., Fisinin, V.I. and Velichko, O.A. (2018) Selenium in poultry nutrition: From sodium selenite to organic selenium sources. J. Poult. Sci., 55(2): 79-93.

58. Li, J.L., Zhang, L., Yang, Z.Y., Zhang, Z.Y., Jiang, Y., Gao, F. and Zhou, G.H. (2018) Effects of different selenium sources on growth performance, antioxidant capacity and meat quality of local Chinese subei chickens. Biol. Trace Elem. Res., 181(2): 340-346.

59. Cai, S.J., Wu, C.X., Gong, L.M., Song, T., Wu, H. and Zhang, L.Y. (2012) Effects of nano-selenium on performance, meat quality, immune function, oxidation resistance, and tissue selenium content in broilers. Poult. Sci., 91(10): 2532-2539.

60. Bakhshalinejad, R., Kakhki, R.A.M. and Zoidis, E. (2018) Effects of different dietary sources and levels of selenium supplements on growth performance, antioxidant status and immune parameters in ross 308 broiler chickens. Br. Poult. Sci., 59(1): 81-91.

61. Xiao, X., Yuan, D., Wand, Y.X. and Zhan, X.A. (2016) The protective effects of different sources of maternal selenium on oxidative stressed chick embryo liver. Biol. Trace Elem. Res., 172(1): 201-208.

62. Gulyas, G., Csosz, E., Prokisch, J., Javor, A., Mezes, M., Erdelyi, M., Balogh, K., Janaky, T., Szabo, Z., Simon, A. and Czegledi, L. (2016) Effect of nano-sized, elemental selenium supplement on the proteome of chicken liver. $J$. Anim. Phys. Anim. Nutr., 101(3): 502-510.

63. Da Silva, I.C.M., Ribeiro, A.M.L., Canal, C.W., Trevizan, L., Macagnan, M., Goncalves, T.A., Hlavac, N.R.C., de Almeida, L.I. and Pereira, R. (2010) The impact of organic and inorganic Se on the immune system of growing broilers submitted to immune stimulation and heat stress. Rev. Bras. Ciên. Aví., 12(4): 247-254.

64. Boostani, A., Sedeghi, A.A., Mousavi, S.N., Chamani, M. and Kashan, N. (2015) Effects of organic, inorganic, and nano-se on growth performance, antioxidant capacity, cellular and humoral immune responses in broiler chickens exposed to oxidative stress. Livest Sci., 178(August): 330-336.

65. Barko, P.C., McMichael, M.A., Swanson, K.S. and Williams, D.A. (2017) The gastrointestinal microbiome: A review. J. Vet. Intern. Med., 32(1): 9-25.

66. Gangadoo, S., Stanley, D., Hughes, R.J., Moore, R.J. and Chapman, J. (2016) Nanoparticles in feed: Progress and prospects in poultry research. Trends Food Sci. Technol., 58(December): 115-126.

67. Stanley, D., Geier, M.S., Chen, H., Hughes, R.J. and 
Moore, R.J. (2015) Comparison of fecal and cecal microbiotas reveals qualitative similarities but quantitative differences. BMC Microbiol., 15(1): 1-11.

68. Yip, J., Liu, L., Wong, K.H., Leung, P.H., Yuen, C.W.M. and Cheung, M.C. (2014) Investigation of antifungal and antibacterial effects of fabric padded with highly stable selenium nanoparticles. J. Appl. Polymer Sci., 131(17): 40728.

69. Kheradmand, E., Rafii, F., Yazdi, M.H., Sepahi, A.A., Shahverdi, A.R. and Oveisi, M.R. (2014) The antimicrobial effects of selenium nanoparticle-enriched probiotics and their fermented broth against Candida albicans. DARU, 22(1): 48.

70. Shakibaie, M., Forootanfar, H., Golkari, Y., MohammadiKhorsand, T. and Shakibaie, M.R. (2015) Anti-biofilm activity of biogenic selenium nanoparticles and selenium dioxide against clinical isolates of Staphylococcus aureus, Pseudomonas aeruginosa, and Proteus mirabilis. J. Trace Elem. Med. Biol., 29(January): 235-241.

71. Mohapatra, P., Swain, R.K., Mishra, S.K., Behera, T., Swain, P., Mishra, S.S., Behura, N.C., Sabat, S.C., Sethy, K., Dhama, K. and Jayasankar, P. (2014) Effects of dietary nano-selenium on tissue selenium deposition, antioxidant status and immune functions in layer chicks. Int. J. Pharm., 10(3): 160-167.

72. Wang, Y. (2009) Differential effects of sodium selenite and nano-se on growth performance, tissue Se distribution, and glutathione peroxidase activity of avian broiler. Biol. Trace Elem. Res., 128(2): 184-190.

73. Pan, C., Huang, K., Zhao, Y., Qin, S., Chen, F. and Hu, Q. (2007) Effect of selenium source and level in hen's diet on tissue selenium deposition and egg selenium concentrations. J. Agric. Food Chem., 55(3): 1027-1032.

74. Diskin, C.J., Tomasso, C.L., Alper, J.C., Glaser, M.L. and Fliegel, S.E. (1979) Long-term selenium exposure. Arch. Intern. Med., 139(7): 824-826.

75. Hu, C.H., Li, Y.L., Xiong, L., Zhang, H.M., Song, J. and Xia, M.S. (2012) Comparative effects of nano elemental selenium and sodium selenite on selenium retention in broiler chickens. Anim. Feed Sci. Tech., 177(3-4): 204-210.

76. Food Standards Australia New Zealand. (2003) The $20^{\text {th }}$ Australian Total Diet Survey. FSANZ, Canberra.

77. National Health and Medical Research Council. (2001b) National Health and Medical Research Council Website. Available from: https://www.nhmrc.gov.au/health-advice/ nutrition. Retrieved on 26-08-2020.

78. Gangadoo, S., Dinev, I., Willson, N.L., Moore, R.J., Chapman, J. and Stanley, D. (2020) Nanoparticles of selenium as high bioavailable and non-toxic supplement alternatives for broiler chickens. Environ. Sci. Pollut. Res., 27(14): 16159-16166.

79. Shi, L., Xun, W., Yue, W., Zhang, C., Ren, Y., Shi, L., Wang, Q., Yang, R. and Lei, F. (2011) Effect of sodium selenite, Se-yeast and nano-elemental selenium on growth performance, Se concentration and antioxidant status in growing male goats. Small Rumin. Res., 96(1): 49-52.

80. Alkhudhayri, A.A., Dkhil, M.A. and Al-Quraishy, S. (2018) Nanoselenium prevents eimeriosis-induced inflammation and regulates mucin gene expression in mice jejunum. Int. J. Nanomed., 13(April): 1993-2003.

81. Mousa, D.M. and Ali, B.H. (2018) Impact of boron and nano-boron on the heterophil/lymphocyte ratio and histopathological changes of liver and kidney in broiler chicken infected with Escherichia coli. Basrah J. Vet. Res., 17(3): 290-306.

82. Selim, N.A., Radwan, N.L., Youssef, S.F., Salah Eldin, T.A. and Abo Elwafa, S. (2015) Effect of inclusion inorganic, organic or nano selenium forms in broiler diets on: 2-physiological, immunological and toxicity statuses of broiler chicks. Int. J. Poult. Sci., 14(3): 144-155.

83. Attia, Y.A., Abdalah, A.A., Zeweil, H.S., Bovera, F., Tag El-Din, A.A. and Araft, M.A. (2010) Effect of inorganic or organic selenium supplementation on productive performance, egg quality and some physiological traits of dual-purpose breeding hens. Czech J. Anim. Sci., 55(11): 505-519. 